\title{
UNRAVELLING REDRESS FOR INSTITUTIONAL ABUSE OF CHILDREN IN AUSTRALIA
}

\author{
KATHLEEN DALY* AND JULIET DAVIS**
}

\begin{abstract}
This article chronicles the evolution of Australia's National Redress Scheme for institutional child sexual abuse. It provides a comprehensive analysis of what occurred from the release of the Royal Commission's redress recommendations in September 2015 to early July 2019, capturing the twists and turns of legislative changes, government statements, and media stories. We chart the parliamentary processes that culminated in the scheme's commencement on 1 July 2018 and analyse the changing treatment of 17 contentious matters at the heart of the scheme. Constitutional limits on federal power meant that federal and state governments had to negotiate and compromise in creating a single national scheme. In the process, the redress scheme unravelled: 14 of 17 matters shifted moderately or significantly away from the Royal Commission's recommendations and redress principles. Future changes to the scheme will require substantial renegotiations and a shift in position on increased costs.
\end{abstract}

\section{INTRODUCTION}

On 1 July 2018, the National Redress Scheme for people who have experienced institutional child sexual abuse ('NRS') commenced.' This article examines the evolution of the NRS from the release of the recommendations for redress by the Royal Commission into Institutional Responses to Child Sexual Abuse ('Royal Commission') in September 2015 to early July 2019. The NRS was

* $\quad$ BA (Anthropology), MEd, PhD (Sociology) (University of Massachusetts), Professor, School of Criminology and Criminal Justice, Griffith University.

** BA, LLB (Hons) (UQ), MA (Columbia University), MSc (London School of Economics and Political Science), Research Fellow, Griffith Criminology Institute, Griffith University.

Our thanks and appreciation to the three anonymous reviewers and to our colleagues (Frank Golding, Anne Tiernan, and Jacob Deem) for sharing their knowledge and insights. Thanks also to Senior Research Assistant Victoria Meyer and Research Assistant Evelyn Hoare for their editorial review and assistance. This work was supported by the Australian Research Council under Grant DP170101470 (2017-20). The information in this article was current as of 11 July 2019.

1 'National Redress Scheme for People Who Have Experienced Institutional Child Sexual Abuse', Australian Government, Department of Social Services (Web Page, 17 December 2018)

$<$ https://www.dss.gov.au/national-redress-scheme-for-people-who-have-experienced-institutional-childsexual-abuse $>$. 
not the result of a simple political exercise governed by clear policy goals. Rather, its evolution was shaped by political compromises across jurisdictional and party lines. Constitutional limits on federal power compelled federal and state governments to work together to forge a single national scheme; but economic, political, and operational concerns fostered compromise and controversy. The negotiated nature of the scheme was made clear in Minister Porter's description of the Commonwealth Redress Scheme for Institutional Child Sexual Abuse Bill 2017 (Cth) (the precursor to the NRS) as 'a significant first step to encourage jurisdictions to opt-in to the Scheme ...'2 The major elements of the NRS were a compromise between the policy aim of ensuring comprehensive participation and the partisan interests of the Commonwealth, states, and non-governmental institutions. In the maelstrom of political and policy wrangling, over $80 \%$ of the scheme's elements were altered in ways that departed from the spirit of the Royal Commission's recommendations. Our article shows how and why the unravelling took place.

Part II provides an overview of the legislative processes underpinning the redress scheme's establishment. Part III examines 17 contentious matters at the heart of the redress scheme and their changing treatment during the legislative process. Some received considerable attention by the media and advocacy groups, but others remained in the shadows. Part IV analyses the degree to which the NRS adheres to or deviates from the Royal Commission's principles of redress.

The findings are four-fold:

1. The Federal Government's intended start date of the scheme (1 July 2018) effectively tied the hands of Parliament. Members passed the National Redress Scheme for Institutional Child Sexual Abuse Bill 2018 (Cth) ('NRS Bill'), despite its many flaws, because any proposed amendments would require re-negotiating the redress framework decided by members of the state and federal executive.

2. Considerable media and advocacy attention was devoted to five contentious matters: the monetary payment cap, criminal history exclusion, eligible abuse, funding for counselling and psychological care, and the assessment framework. Important as these were, 12 other consequential matters were overlooked. Grouped thematically, they were the direct personal response, scheme coverage, application process, other eligibility requirements, and scheme oversight. Although some have since received greater attention, their place in the shadows has fostered a restricted understanding of the NRS.

3. Of 17 matters, 14 saw moderate or significant change in the NRS from what the Royal Commission had recommended. Such change can be explained by the economic and political interests of governments and institutions and by operator convenience.

2 Letter from Christian Porter to Helen Polley, 30 November 2017, 1, reproduced in Ministerial Responses to Senate Standing Committee for the Scrutiny of Bills, Parliament of Australia, Scrutiny Digest (Digest No 15 of 2017, 30 November 2017). 
4. Of 14 matters that saw change, departure from three of the Royal Commission's redress principles was typical. All 14 departed from the principle of being survivor focused, six from the principle of having regard to the nature and impact of child sexual abuse, and nine from the principle of having regard to the needs of particularly vulnerable survivors.

The legislative story of the NRS is not over. A Commonwealth Joint Select Committee on Oversight of the Implementation of Redress Related Recommendations of the Royal Commission into Institutional Responses to Child Sexual Abuse ('Joint Select Committee') received submissions and held hearings from October 2018 to February 2019. ${ }^{3}$ It gathered evidence on implementation problems and on scheme elements that were revealed to politicians only after passage of NRS legislation in June 2018. The Joint Select Committee tabled its report on 2 April 2019. It made 29 recommendations for significant change to the scheme. ${ }^{4}$ The Morrison Government's response to the report is forthcoming. These developments are sketched briefly in Part VI.

\section{THE PATH TO THE REDRESS SCHEME}

\section{A The Royal Commission into Institutional Responses to Child Sexual Abuse}

The Royal Commission was announced by then Prime Minister Julia Gillard on 12 November 2012. ${ }^{5}$ This appointment was the culmination of decades of advocacy by survivors of institutional abuse and child sexual abuse. ${ }^{6}$ At the press conference, journalists queried whether state premiers would wish to cooperate with the Royal Commission and asked whether there would be 'widespread resistance' from church groups. ${ }^{7}$ Although these concerns were set aside by the

3 'Joint Select Committee on Oversight of the Implementation of Redress Related Recommendations of the Royal Commission into Institutional Responses to Child Sexual Abuse', Parliament of Australia (Web Page) <https://www.aph.gov.au/Parliamentary_Business/Committees/Joint/Royal_Commission_into_ Institutional_Responses_to_Child_Sexual_Abuse/RoyalCommissionChildAbuse $>$.

4 Joint Select Committee on Oversight of the Implementation of Redress Related Recommendations of the Royal Commission into Institutional Responses to Child Sexual Abuse, Getting the National Redress Scheme Right: An Overdue Step Towards Justice (Final Report, April 2019) ix-xiii ('Joint Select Committee Final Report').

$5 \quad$ 'Final Report', Royal Commission into Institutional Responses to Child Sexual Abuse (Web Page) $<$ https://www.childabuseroyalcommission.gov.au/final-report>.

6 Royal Commission into Institutional Responses to Child Sexual Abuse (Final Report, December 2017) vol 1, 2 ('Final Report'). For care leaver advocacy groups, whose members comprise about half of estimated abuse survivors, a bitter irony is not lost. Their decades-long advocacy eventuated in a Royal Commission and redress scheme, but because the focus was on sexual abuse alone, care leavers' abuse experiences in closed institutions and foster care were bypassed, and their claims for justice, not realised. For further discussion see Katie Wright and Shurlee Swain, 'Speaking the Unspeakable, Naming the Unnameable: The Royal Commission into Institutional Responses to Child Sexual Abuse' (2018) 42(2) Journal of Australian Studies 139, which serves as the introduction to a special issue on the Royal Commission.

7 Parliament of Australia, 'Royal Commission into Child Sexual Abuse' (Transcript of Press Conference, 12 November 2012). 
Prime Minister, they foreshadowed problems of cooperation that would be central to the establishment of a national redress scheme.

As part of its remit, the Royal Commission was tasked with investigating

what institutions and governments should do to address, or alleviate the impact of, past and future child sexual abuse and related matters in institutional contexts, including, in particular, in ensuring justice for victims through the provision of redress by institutions ... 8

The Royal Commission ran for almost five years, delivering its 17 -volume Final Report to the Governor-General on 15 December 2017.9 It received the personal recollections of thousands of survivors in 8,013 face-to-face private sessions and 1,344 written accounts..$^{10}$ More than two years earlier, in September 2015, it released the Redress and Civil Litigation Report, stating that 'our society's failure to protect children across a number of generations makes clear the pressing need to provide avenues through which survivors can obtain appropriate redress for past abuse'. ${ }^{11}$

The Royal Commission decided to expedite its redress report and recommendations to provide more certainty to survivors and institutions, recognising that many survivors were aging. It made 75 redress recommendations, including the establishment of a single national redress scheme. ${ }^{12}$ The Royal Commission concluded that a national approach would provide redress to survivors more effectively than individual state and territory schemes, or schemes run by non-government institutions. However, it recognised that a national scheme's establishment would be 'likely to require significant national negotiations and that these negotiations are likely to take some time'. ${ }^{13}$ On 29 January 2016, the Federal Government announced that it would lead 'the development of a national approach to redress for survivors of institutional child sexual abuse'. ${ }^{14}$ As we show, this undertaking was fraught with difficulty from the outset.

\section{B The Legislative Process}

The Australian redress scheme evolved slowly over several years before a crescendo of activity occurred in 2018 (a chronology is shown in the Appendix). Australia's constitutional framework was pivotal to the scheme's development.

8 'Letters Patent', Royal Commission into Institutional Responses to Child Sexual Abuse (Web Page, 11 January 2013)<https://www.childabuseroyalcommission.gov.au/terms-reference>.

9 Royal Commission into Institutional Responses to Child Sexual Abuse, 'Final Report Released' (Media Release, 15 December 2017).

10 Royal Commission into Institutional Responses to Child Sexual Abuse, Final Information Update (Fact Sheet, 24 November 2017) 1.

11 Royal Commission into Institutional Responses to Child Sexual Abuse (Redress and Civil Litigation Report, 2015) 5 ('Redress and Civil Litigation Report').

12 Ibid 26 (Recommendation 26). The remaining 24 recommendations in the report focused on interim arrangements and civil litigation.

13 Ibid.

14 Christian Porter and George Brandis, 'Developing a National Approach to Redress for Survivors of Institutional Child Sexual Abuse' (Media Release, Department of Social Services, 29 January 2016) < https://formerministers.dss.gov.au/17498/developing-a-national-approach-to-redress-for-survivors-ofinstitutional-child-sexual-abuse/>. 
Australia is regarded as one of the world's most centralised federations, with significant power bestowed on the Commonwealth due to its greater fiscal capacity. ${ }^{15}$ However, constitutional limits on the Commonwealth's powers meant that it was unable to pass laws establishing a national redress scheme without state involvement, nor legislatively compel states to participate. ${ }^{16}$ Each state government could choose to refer the redress scheme 'matter' to the Commonwealth under section 51(xxxvii) of the Australian Constitution, a formal step that would then allow the Commonwealth to legislate with respect to the referring state. Without state referral, non-Commonwealth institutions, both government and non-government, could not participate in the redress scheme.

Referral of states' legislative powers to the Commonwealth involved not only a handover of power, but also the imposition of a significant fiscal burden. The Royal Commission recommended that the entity responsible for the abuse should bear the cost of funding the redress claim. ${ }^{17}$ Additionally, it recommended that participating governments become the 'funders of last resort' for claims in which the responsible entity was bankrupt or defunct. ${ }^{18}$ Clearly, significant intergovernmental negotiations were going to be required.

Negotiations began in January 2016 and moved slowly. In the latter half of 2017, many observers were pessimistic that a national scheme would come to fruition. ${ }^{19}$ The Turnbull Coalition Government was in a weak political position after the 2016 federal election, having been returned with a tenuous one-seat majority in the House of Representatives. ${ }^{20}$ The Coalition's power was also reduced in the Senate, with three fewer Coalition senators elected and a larger cross-bench. ${ }^{21}$ The Federal Government did not have a sufficiently strong mandate to compel the participation of state governments, half of which were Labor-led, by political will alone.

On 4 November 2016, then Attorney-General George Brandis and then Minister for Social Services Christian Porter announced in a press release that the Federal Government would establish a Commonwealth redress scheme. ${ }^{22}$ The Government's strategy was to establish a scheme for abuse that had occurred in Commonwealth institutions, while encouraging state and territory governments and non-government institutions to opt in. ${ }^{23}$ This permitted the Commonwealth Government to set up a more limited scheme quickly, in line with the Royal

15 Louise Chappell and Mayet Costello, 'Australian Federalism and Domestic Violence Policy-Making' (2011) 46(4) Australian Journal of Political Science 633, 636.

16 Section 51 of the Australian Constitution only grants power to the Commonwealth government to legislate with respect to specific matters such as trade and commerce, quarantine, and marriage.

17 Redress and Civil Litigation Report (n 11) 334 (Recommendation 35(a)).

18 Ibid 341 (Recommendation 36).

19 Kathleen Daly, 'Listen to Abuse Survivors and Advocates to Clear the Way to a National Redress Scheme', The Conversation (online, 8 February 2018) $<$ https://theconversation.com/listen-to-abusesurvivors-and-advocates-to-clear-the-way-to-a-national-redress-scheme-90925>.

20 Damon Muller, 'Double, Double Toil and Trouble: The 2016 Federal Election' (Research Paper, Parliamentary Library, Parliament of Australia, 30 June 2017) 1.

21 Ibid 15.

22 Christian Porter and George Brandis, 'Commonwealth Redress Scheme for Survivors of Institutional Child Sexual Abuse’ (Media Release, Department of Social Services, 4 November 2016). Ibid. 
Commission's recommendations. ${ }^{24}$ As such, the proposed Commonwealth Redress Scheme ('CRS') provided a temporary solution to a time-sensitive policy problem. ${ }^{25}$

In May 2017, the Federal Government announced that the redress scheme would be open for applications from July 2018. ${ }^{26}$ This starting date was an important policy commitment for the Turnbull Government. Legislative efforts were focused on readying the CRS to meet this deadline. ${ }^{27}$ On 26 October 2017, the Commonwealth Redress Scheme for Institutional Child Sexual Abuse Bill 2017 ('CRS Bill') and the Commonwealth Redress Scheme for Institutional Child Sexual Abuse (Consequential Amendments) Bill 2017 were introduced into the House of Representatives. ${ }^{28}$

As the CRS legislation began to run the legislative gauntlet, the Federal Government continued to encourage state and territory governments, and nongovernment institutions, to join a national scheme. ${ }^{29}$ However, state participation in a national scheme seemed unlikely. Minister Porter criticised this stance in February 2018: 'Excuses for failing to join the scheme must end. Lingering reasons for the delay are now starting to look to any independent observer as if minor details are being manifestly and deliberately used as excuses for needless delay'. ${ }^{30}$

A breakthrough in intergovernmental negotiations took place the following month. On 9 March 2018, it was announced that New South Wales and Victoria had agreed to join the scheme. ${ }^{31}$ This decision also created an avenue for nongovernment institutions in those states to participate. ${ }^{32}$ Prime Minister Turnbull urged the remaining jurisdictions to follow the lead of New South Wales and Victoria. ${ }^{33}$ Over the next three months, other states progressively announced their intention to join the scheme. ${ }^{34}$

24 Redress and Civil Litigation Report (n 11) 27.

25 As part of this process, the Commonwealth established a 15-member Redress Advisory Council in December 2016. The Council met throughout 2017 to advise the Commonwealth on the CRS. For completeness, it should be noted that the first author was a member of the Council; however, all information discussed arises from the public record.

26 Christian Porter and George Brandis, 'Commonwealth Redress Scheme for Survivors of Institutional Child Sexual Abuse’ (Media Release, Department of Social Services, 9 May 2017).

27 Department of Social Services and Department of Human Services (Cth), Submission No 19 to the Joint Select Committee on Oversight of the Implementation of Redress Related Recommendations of the Royal Commission into Institutional Responses to Child Sexual Abuse, Parliament of Australia 1.

28 Department of Parliamentary Services (Cth), Bills Digest (No 120 of 2017-18, 18 June 2018) 8. The Commonwealth Redress Scheme for Institutional Child Sexual Abuse (Consequential Amendments) Bill 2017 (and its NRS successor) amended other existing pieces of legislation to ensure that they reflected the purpose of the new scheme.

29 Department of Social Services and Department of Human Services (n 27) 1.

30 Commonwealth, Parliamentary Debates, House of Representatives, 8 February 2018, 789 (Christian Porter, Attorney-General).

31 'NSW and Victoria Join National Abuse Redress Scheme', ABC News (online, 9 March 2018) $\Varangle$ ttps://www.abc.net.au/news/2018-03-09/nsw-and-victoria-join-redress-scheme/9531606>.

32 Malcolm Turnbull, Gladys Berejiklian and Daniel Andrews, 'First States Commit to Redress Scheme' (Media Release, Parliament of Australia, 9 March 2018) 2.

33 Ibid 1.

34 Queensland (30 April 2018), Tasmania (22 May 2018), South Australia (28 May 2018), and Western Australia (27 June 2018). 
The Australian Constitution contains scant detail about how federal and state governments should cooperate to achieve national policy objectives. This has led to the emergence of institutional arrangements such as ministerial councils, intergovernmental agreements, and heads of government meetings. ${ }^{35}$ On 1 May 2018, the Premier of New South Wales and the Chief Minister of the Australian Capital Territory became the first signatories of the Council of Australian Governments ('COAG') Intergovernmental Agreement on the National Redress Scheme for Institutional Child Sexual Abuse ('Intergovernmental Agreement'), ${ }^{36}$ which set out how federal, state, and territory governments would work together to implement a national redress scheme.

Also on 1 May, New South Wales became the first state to introduce legislation that referred powers to the federal government to enact the text of the National Redress Scheme Bill and make amendments to the Bill. ${ }^{37}$ The Intergovernmental Agreement required that all referral or adoption legislation passed by the states would be 'in substantially the same terms' as New South Wales' referral legislation. ${ }^{38}$ The introduction of New South Wales' referral legislation gave the federal government the necessary legislative power to move beyond a Commonwealth redress scheme and establish a national scheme.

On 10 May 2018, the National Redress Scheme for Institutional Child Sexual Abuse Bill 2018 (Cth) and the National Redress Scheme for Institutional Child Sexual Abuse (Consequential Amendments) Bill 2018 (Cth) (the 'NRS Bills') were introduced into Commonwealth Parliament. ${ }^{39}$ The National Redress Scheme for Institutional Child Sexual Abuse Rules 2018 (Cth) ('NRS Rules') were also introduced. The NRS Bill allowed the NRS Rules to prescribe key elements of the scheme. ${ }^{40}$ This reliance on delegated legislation was justified by the federal government on the grounds that it allowed the scheme to be more 'flexible and adaptable to the realities of implementation' ${ }^{41}$ However, it also granted significant

35 John Phillimore and Linda Botterill, "Why We Need Clear Rules between the States and Commonwealth', The Conversation (online, 15 September 2014) $<$ https://theconversation.com/why-weneed-clear-rules-between-the-states-and-commonwealth-31368>.

36 Council of Australian Governments, 'Intergovernmental Agreement on the National Redress Scheme for Institutional Child Sexual Abuse' (4 May 2018) 15 ('Intergovernmental Agreement').

37 National Redress Scheme for Institutional Child Sexual Abuse (Commonwealth Powers) Bill 2018 (NSW); Legislation Review Committee, Parliament of NSW, Legislation Review Digest (Digest No 54/56 of 2018, 15 May 2018) 8.

38 Intergovernmental Agreement (n 36) $\mathrm{cl} 16$.

39 Department of Social Services and Department of Human Services (n 27) 1.

40 Department of Social Services, Submission No 27 to Senate Standing Committee on Community Affairs, Parliament of Australia, Commonwealth Redress Scheme for Institutional Child Sexual Abuse Bill 2017 and Related Bill (6 February 2018) 2, cited in Community Affairs Legislation Committee, Parliament of Australia, Commonwealth Redress Scheme for Institutional Child Sexual Abuse Bill 2017 and Commonwealth Redress Scheme for Institutional Child Sexual Abuse (Consequential Amendments) Bill 2017 (Final Report, 28 March 2018) 26-7. These elements included whether a person would be entitled to redress under the scheme: National Redress Scheme for Institutional Child Sexual Abuse Act 2018 (Cth) s 12 ('NRS Act'), whether they were eligible for redress: NRS Act s 13, and whether the abuse fell within the scope of the scheme: NRS Act $\mathrm{s} 14$.

41 Explanatory Memorandum, National Redress Scheme for Institutional Child Sexual Abuse Bill 2018 (Cth) 21 ('Explanatory Memorandum, NRS Bill'). 
power to the responsible minister at the expense of Parliament, resulting in less policy stability and parliamentary oversight.

Although many non-Coalition members expressed reservations about the NRS Bills, they voted to pass them because 'on an issue like this, we should not seek to make the perfect the enemy of the acceptable'. ${ }^{42}$ The decision to pass the NRS Bills was often couched in pro-survivor rhetoric, ${ }^{43}$ such as: "Survivors have in some instances waited all their lives for justice, and they should not have to wait a minute longer' ${ }^{44}$ In fact, the federal Parliament had effectively been presented with a fait accompli. Any changes to the NRS Bills would effectively void the referral of powers and require re-negotiations with the participating states, jeopardising the scheme's promised start date. ${ }^{45}$ Senator Rachel Siewert later described the situation faced by parliamentarians:

One issue that keeps coming up is that you have to talk to states and territories about amendments. In the Senate, when we tried to make amendments, that was the response - 'We can't make any amendments.' Quite frankly, it was 'take it or leave it' with this legislation because of the time frame. You're probably aware that I asked lots and lots of questions but the answer was always, 'We can't amend it because of the states and territories, and, by the way, it's a minute to midnight' we were debating this in June and it was supposed to start in July. To say that the Senate passed the legislation: we passed it, essentially, with the threat, 'This is under duress' ... ${ }^{46}$

The NRS Bills were passed without amendment on 19 June 2018,47 enabling the redress scheme to commence in New South Wales, Victoria, and the Australian Capital Territory by 1 July $2018 .{ }^{48}$

On 13 August 2017, several months after the NRS Bills were passed, two crucial pieces of delegated legislation were tabled in federal Parliament: the National Redress Scheme for Institutional Child Sexual Abuse Assessment

42 Commonwealth, Parliamentary Debates, House of Representatives, 24 May 2018, 4559 (Bill Shorten, Leader of the Opposition).

43 See Commonwealth, Parliamentary Debates, Senate, 18 June 2018. 'We are committed to improving these imperfect pieces of legislation, but we think we need to get this started. Survivors have waited for far too long': at 3032 (Rachel Siewert, Australian Greens Whip); 'calls to scrap the current scheme and start again would be cruel to other victims who've waited so long': at 3044 (Derryn Hinch); 'It would be cruel to now propose any amendment, no matter how well intentioned, to improve the scheme and thereby cause yet another delay in their journey to acknowledgement and recovery': at 3143 (Stirling Griff); 'We know that these survivors have waited far too long, so any more delay or inaction in the delivery of this Redress Scheme is simply unwarranted': at 3155 (Lisa Singh).

44 Ibid 3031 (Louise Clare Pratt).

45 Department of Parliamentary Services (Cth), Bills Digest, (Digest No 120 of 2017-18, 18 June 2018) 14, referring to Senate Standing Committees on Community Affairs, Parliament of Australia, National Redress Scheme for Institutional Child Sexual Abuse Bill 2018 [Provisions] and National Redress Scheme for Institutional Child Sexual Abuse (Consequential Amendments) Bill 2018 [Provisions] (Report, 15 June 2018) 46; Joint Select Committee Final Report (n 4$) 8$.

46 Evidence to Joint Select Committee on Oversight of the Implementation of Redress Related Recommendations of the Royal Commission into Institutional Reponses to Child Sexual Abuse, Parliament of Australia, Canberra, 28 February 2019, 23 (Rachel Siewert) ('Evidence to Joint Select Committee').

47 'National Redress Scheme for Institutional Child Sexual Abuse (Consequential Amendments) Bill', Parliament of Australia (Web Page) $<$ https://www.aph.gov.au/Parliamentary_Business/Bills_Legislation/ Bills_Search_Results/Result?bId=r6102>. Department of Social Services and Department of Human Services (n 27) 1. 
Framework 2018 (Cth) ('Assessment Framework') and the National Redress Scheme for Institutional Child Sexual Abuse Direct Personal Response Framework 2018 (Cth). Members of Parliament were not provided with these frameworks, which included the assessment matrices for monetary payments and counselling, when deliberating on the NRS legislation. Senator Siewert stated that '[m]any times people asked for the matrix, to be able to see it to be able to understand the basis on which these decisions were made, but that was not available at the time we voted on the bill' ${ }^{49}$ Since its release, the Assessment Framework has come under significant criticism.

Since the Commonwealth Parliament's enactment of the National Redress Scheme for Institutional Child Sexual Abuse Act 2018 (Cth) ('NRS Act'), all remaining states have introduced model legislation that adopts the NRS Act and refers power to the Commonwealth to make further amendments. ${ }^{50}$ The Western Australian government's decision to join the scheme was delayed due to the Commonwealth government's initial disavowal of responsibility for the abuse of child migrants sent to Australia as part of a Commonwealth policy, about half of whom were sent to Western Australia. However, the federal government ultimately agreed to be held equally responsible, and Western Australia became the last state to join the scheme. ${ }^{51}$ Because the territories were not obliged to refer legislative powers or pass adoption legislation to opt into the scheme, the Northern Territory always fell within the scheme's scope..$^{52}$

State government participation allowed non-government institutions in all Australian jurisdictions to join the scheme. On 31 May 2018, the Catholic Church became the first major non-government institution to announce its intention to join the scheme; ${ }^{53}$ however, the first Catholic institutions did not formally join the scheme until 12 December $2018 .{ }^{54}$ Since then, several organisations, including the Anglican Church, Salvation Army, Scouts Australia, YMCA Australia, the Uniting Church, and the Lutheran Church of Australia, have announced their intention to participate in the redress scheme. ${ }^{55}$ Non-government institutions are required to undertake several steps prior to being formally declared participants in the

49 Airlie Ward, 'Anglican Church Horrified Over How Redress Scheme Calculates Payments to Victims', $A B C$ News (online, 16 September 2018) <https://www.abc.net.au/news/2018-09-16/anglican-churchhorrified-over-national-redress-calculations/10236812>.

50 Department of Social Services and Department of Human Services (n 27) 2-3.

51 'WA Joins Child Sex Abuse Redress Scheme', SBS News (online, 27 June 2018) $<$ https://www.sbs.com.au/news/wa-joins-child-sex-abuse-redress-scheme>. National Redress Scheme for Institutional Child Sexual Abuse Rules 2018 (Cth) s 10(2) provides that the federal government would be regarded as equally responsible for the abuse of child migrants from the United Kingdom and Malta as state or territory government institutions, as well as any relevant non-government institutions. See also Kathleen Daly, Redressing Institutional Abuse of Children (Palgrave Macmillan, 2014) 47-8.

52 Department of Social Services and Department of Human Services (n 27) 2.

53 Mary Lloyd, 'National Redress Scheme Could Leave Claimants Worse Off, Lawyers and Survivors Warn', ABC News (online, 1 June 2018) < https://www.abc.net.au/news/2018-06-01/survivors-warnclaimants-could-be-worse-off-under-redress-scheme/9822658>.

54 Paul Fletcher, 'First Catholic Institutions Join National Redress Scheme' (Media Release, Department of Social Services, 12 December 2018).

55 Department of Parliamentary Services (Cth), Bills Digest (Digest No 120 of 2017-18, 18 June 2018) 1819; Bishop John Henderson, 'National Redress Scheme (Australia)', Lutheran Church of Australia (Web Page, 16 June 2018) <https://www.lca.org.au/national-redress-scheme-australia/>. 
scheme. ${ }^{56}$ These steps include demonstrating their capacity and commitment to provide monetary redress and a 'meaningful' direct personal response, completing necessary training, providing 'details of current and historic institutional information', and entering into a memorandum of understanding with the Commonwealth. ${ }^{57}$ Certain religious institutions have also taken the additional step of creating a new legal entity to represent their institution's network of independent dioceses, welfare agencies, and schools. ${ }^{58}$ As of 17 May 2019, 39 groups of nongovernment institutions were declared participants in the scheme. ${ }^{59}$

Although more non-government institutions are yet to join, the Royal Commission's recommendation of a single national redress scheme has been implemented. The importance, and difficulty, of realising this goal cannot be underestimated. However, Australia's political system made redress contingent on forging agreement among disparate stakeholders and, as we shall argue, keeping economic and political costs as low as possible. The need for input and negotiation by two tiers of government placed power in the hands of the executive, both state and federal, and sidelined the Parliament. The negotiated character of the scheme required considerable operator flexibility in scheme elements and thus, a lack of policy permanence. This problem was foreshadowed by the Senate Standing Committee for the Scrutiny of Bills in December 2017. The committee advocated a delay in the introduction of legislation in order for policy matters to be considered appropriately, rather than leaving important policy content to delegated legislation. ${ }^{60}$ However, this advice was not followed, and in the race to meet the 1 July 2018 deadline, the spirit of the Royal Commission's recommendations was lost.

\section{CONTENTION AND UNRAVELLING}

\section{A Matters of Contention}

Parliamentary committees, politicians, survivors, survivor advocates, and members of the general public have lodged concerns about the Commonwealth Redress Scheme and the National Redress Scheme. We identified 17 key matters

56 Department of Social Services and Department of Human Services (n 27) 3.

57 Fletcher (n 54).

58 Evidence to Senate Community Affairs Legislation Committee on the Inquiry into the Commonwealth Redress Scheme for Institutional Child Sexual Abuse Bill 2017, Commonwealth Redress Scheme for Institutional Child Sexual Abuse (Consequential Amendments) Bill 2017, Parliament of Australia, Canberra, 16 February 2018, 61-2 (Anne Hywood, General Secretary, Anglican Church of Australia) ('Evidence to the Senate Community Affairs Legislation Committee on the Commonwealth Redress Scheme').

59 National Redress Scheme for Institutional Child Sexual Abuse Declaration 2018 (Cth) s 9. The majority of these groups are constituted by a substantial number of related institutions, including regional associations, archdiocese, parishes, schools, ecclesiastical organisations, trust corporations, and children's homes.

60 Senate Standing Committee for the Scrutiny of Bills, Parliament of Australia, Scrutiny Digest (Digest No 15 of 2017, 6 December 2017) 17 [2.25]. 
of contention by analysing parliamentary materials ${ }^{61}$ along with media coverage of legislation, from late October 2017 to late June 2018. This was supplemented by submissions to and hearings of the Joint Select Committee, whose primary aim was to inquire into 'the Australian Government policy, program and legal response to the redress related recommendations of the Royal Commission'. ${ }^{62}$ The Joint Select Committee materials identified matters of contention that emerged postpassage of the NRS Act.

The 17 matters and associated Royal Commission recommendations are shown in Table 1 (columns 1 and 2). The 17 directly or indirectly condense the content of $64 \%$ of the Royal Commission's 75 redress recommendations, and we believe that they cover all the relevant matters. ${ }^{63} \mathrm{We}$ draw on newspaper jargon to describe two broad categories of matters. Listed first in column 1 are the 'headliners': matters brought forward most often in parliamentary review, submissions and hearings to relevant committees, and by the media and advocacy groups. Listed next are the 12 'buried leads': matters that received less attention than the headliners, despite being consequential for survivors. These are grouped thematically.

61 Ibid; Parliamentary Joint Committee on Human Rights, Parliament of Australia, Human Rights Scrutiny Report (Report, 13 February 2018); Senate Standing Committee, Parliament of Australia, Commonwealth Redress Scheme for Institutional Child Sexual Abuse Bill 2017 and Related Bill (Hearing No 1, 16 February 2018); Senate Standing Committee, Parliament of Australia, Commonwealth Redress Scheme for Institutional Child Sexual Abuse Bill 2017 and Related Bill (Hearing No 2, 6 March 2018); Senate Community Affairs Legislation Committee, Parliament of Australia, Commonwealth Redress Scheme for Institutional Child Sexual Abuse Bill 2017 [Provisions] (Final Report, March 2018); Senate Community Affairs Legislation Committee, Parliament of Australia, National Redress Scheme for Institutional Child Sexual Abuse Bill 2018 and National Redress Scheme for Institutional Child Sexual Abuse (Consequential Amendments) Bill 2018 (Report, June 2018).

62 'Joint Select Committee on Oversight of the Implementation of Redress Related Recommendations of the Royal Commission into Institutional Responses to Child Sexual Abuse’ (n 3).

63 The 17 matters encompass 48 of 75 Royal Commission recommendations on redress (directly or indirectly). The reasons that 27 recommendations were not included were as follows: they dealt with matters external to the redress scheme itself (establishing the scheme, conducting outreach, and external sanctions [20 recommendations]); they were about non-controversial definitions (three recommendations); or they concerned operational requirements for individual assessments (four recommendations). The specific recommendations not included were as follows: the hypothetical situation in which a single national redress scheme was not announced (Recommendations 27, 30); general scheme funding (Recommendations 34, 35, 38-42); certain eligibility criteria (Recommendations 44-6); the publicising of the scheme (Recommendations 49-50); the funding and selection of support services (Recommendations 3, 52-3); evidential support for applications (Recommendations 54-7); and the redress scheme's interactions with alleged abusers and the police (Recommendations 70-5). 
Table 1: Redress scheme provisions: change and degree of change from the Royal Commission's ('RC') recommendations to the NRS

\begin{tabular}{|l|l|l|l|l|}
\hline $\begin{array}{l}\text { Matters of } \\
\text { contention } \\
(n=17)\end{array}$ & The RC's recommendations & $\begin{array}{l}\text { Change } \\
\text { from } R C \\
\text { recs to }\end{array}$ & Type of change & $\begin{array}{l}\text { Pressure } \\
\text { point for } \\
\text { change }\end{array}$ \\
$(1)$ & $\begin{array}{l}\text { NRS? } \\
(3)\end{array}$ & $(4)$ & $(5)$ \\
\hline
\end{tabular}

\begin{tabular}{|l|l|l|l|l|}
\hline \multicolumn{2}{|l|}{ A Headliners } \\
\hline $\begin{array}{l}\text { Monetary } \\
\text { payment cap }\end{array}$ & $\$ 200,000$ maximum. & yes & reduced to \$150,000 & economics \\
\hline $\begin{array}{l}\text { Criminal history } \\
\text { exclusion }\end{array}$ & RC did not discuss or specify. & yes & $\begin{array}{l}\text { significant } \\
\text { restriction in } \\
\text { eligibility }\end{array}$ & politics \\
\hline Eligible abuse & Limited to sexual abuse. & no & NA & NA \\
\hline $\begin{array}{l}\text { Counselling } \\
\text { and } \\
\text { psychological } \\
\text { care }\end{array}$ & $\begin{array}{l}\text { Counselling available for the life } \\
\text { of the survivor, with no fixed } \\
\text { limits. Counselling available to } \\
\text { family members. }\end{array}$ & yes & $\begin{array}{l}\text { significant } \\
\text { reduction in amount } \\
\text { and eligibility }\end{array}$ & economics \\
\hline $\begin{array}{l}\text { Assessment } \\
\text { framework }\end{array}$ & $\begin{array}{l}\text { Matrix measuring 'severity of } \\
\text { abuse' (40 points), 'impact of } \\
\text { abuse' (40 points), and } \\
\text { 'additional elements' (20 points). }\end{array}$ & yes & $\begin{array}{l}\text { significant } \\
\text { modification }\end{array}$ & economics \\
\hline
\end{tabular}

\section{B Buried Leads}

\section{Direct personal response}

\begin{tabular}{|l|l|l|l|l|}
\hline $\begin{array}{l}\text { Direct personal } \\
\text { response }\end{array}$ & $\begin{array}{l}\text { Three minimum elements: } \\
\text { apology, a meeting with a senior } \\
\text { institutional representative, a } \\
\text { statement as to steps to prevent } \\
\text { further abuse. }\end{array}$ & yes & $\begin{array}{l}\text { significant } \\
\text { reduction in } \\
\text { responsibilities } \\
\text { of institutions }\end{array}$ & economics \\
\hline Scheme coverage & RC did not discuss or specify. & yes & $\begin{array}{l}\text { some expansion of } \\
\text { institutions' timing } \\
\text { flexibility }\end{array}$ & operations \\
\hline $\begin{array}{l}\text { Timeframe for } \\
\text { institutions to } \\
\text { opt in }\end{array}$ & $\begin{array}{l}\text { significant } \\
\text { reduction in } \\
\text { government role }\end{array}$ & economics \\
\hline $\begin{array}{l}\text { Funder of last } \\
\text { resort }\end{array}$ & $\begin{array}{l}\text { Commonwealth and } \\
\text { state/territory governments to be } \\
\text { 'funders of last resort' to cover } \\
\text { any funding shortfall. }\end{array}$ & yes & \\
\hline Application process
\end{tabular}




\begin{tabular}{|c|c|c|c|c|}
\hline $\begin{array}{l}\text { Single } \\
\text { application }\end{array}$ & RC did not discuss or specify. & yes & $\begin{array}{l}\text { some restriction of } \\
\text { survivors' } \\
\text { strengthening of } \\
\text { claims with new } \\
\text { information }\end{array}$ & operations \\
\hline Indexation & $\begin{array}{l}\text { Previous monetary payments } \\
\text { should be indexed and taken } \\
\text { into account. }\end{array}$ & no & NA & NA \\
\hline $\begin{array}{l}\text { Acceptance } \\
\text { period }\end{array}$ & $\begin{array}{l}\text { One year for survivor to accept } \\
\text { (or not) offer of redress. }\end{array}$ & yes & $\begin{array}{l}\text { some reduction to } \\
\text { six months }\end{array}$ & operations \\
\hline $\begin{array}{l}\text { Deed of } \\
\text { release }\end{array}$ & $\begin{array}{l}\text { Applicant to release the scheme } \\
\text { and institution from liability as a } \\
\text { condition of receiving monetary } \\
\text { payment. }\end{array}$ & yes & $\begin{array}{l}\text { significant } \\
\text { expansion of } \\
\text { released parties }\end{array}$ & economics \\
\hline \multicolumn{5}{|c|}{ Other eligibility requirements } \\
\hline $\begin{array}{l}\text { No application } \\
\text { from gaol }\end{array}$ & RC did not discuss or specify. & yes & $\begin{array}{l}\text { significant } \\
\text { restriction in } \\
\text { eligibility }\end{array}$ & politics \\
\hline $\begin{array}{l}\text { Citizenship/ } \\
\text { residency }\end{array}$ & $\begin{array}{l}\mathrm{RC} \text { had no citizenship or } \\
\text { residency requirements. }\end{array}$ & yes & $\begin{array}{l}\text { significant } \\
\text { restriction in } \\
\text { eligibility }\end{array}$ & politics \\
\hline $\begin{array}{l}\text { Minimum age } \\
\text { at application }\end{array}$ & $\begin{array}{l}\mathrm{RC} \text { had no restriction on } \\
\text { children applying. }\end{array}$ & yes & $\begin{array}{l}\text { some restriction } \\
\text { in eligibility }\end{array}$ & economics \\
\hline \multicolumn{5}{|c|}{ Scheme oversight } \\
\hline $\begin{array}{l}\text { Lack of } \\
\text { external review }\end{array}$ & No external review. & no & NA & NA \\
\hline $\begin{array}{l}\text { Scheme } \\
\text { reporting }\end{array}$ & $\begin{array}{l}\text { Annual publication of data about } \\
\text { applications made, institutions } \\
\text { identified, abuse periods, } \\
\text { finalisation of applications, and } \\
\text { applications for review. }\end{array}$ & yes & $\begin{array}{l}\text { some reduction } \\
\text { in information to } \\
\text { be reported by } \\
\text { operator }\end{array}$ & operations \\
\hline
\end{tabular}

\section{B From the Royal Commission's Recommendations to the NRS}

Table 1 (columns 3 and 4) shows that for 14 of 17 matters, there was moderate or significant change between what the Royal Commission recommended and what is in the NRS. ${ }^{64}$

Of the 14, there was significant change for eight:

64 Our determination of the degree of change (significant or not) is necessarily subjective, and some may dispute our categorisation. For example, the shift from a $\$ 200,000$ to $\$ 150,000$ maximum payment may be a significant change to many, and certainly it has symbolic significance. We also know that the twoyear opt in period for institutions, when coupled with the requirement that each survivor could only submit a single application, has had a significant effect on survivors applying to the scheme. Many are awaiting greater clarity before they apply. Thus, if we have erred, it is in a conservative direction. 
- reduced funding for counselling;

- a new method for calculating the monetary payment (the Assessment Framework);

- reduced responsibilities of institutions to engage in a direct personal response;

- expansion of the deed of release; and

- restrictions on who can apply (criminal history exclusions, application from gaol, citizenship and residency requirements, those unable to apply if an institution no longer existed or was insolvent).

Precisely when change occurred varies. Five matters underwent change under the CRS, and the change was replicated in the NRS. ${ }^{65}$ Two underwent a gradual erosion, with changes made under both the CRS and the NRS. ${ }^{66}$ Two zigzagged in their conceptualisation, from either being relatively liberal or not specified in the Royal Commission, to having a strict application under the CRS, and then relaxing somewhat under the NRS. ${ }^{67}$ Two diverged from the Royal Commission's recommendations only at the NRS stage ${ }^{68}$ For three matters, their content detail was to be given in the CRS rules, which were never released; as such, it is not possible to determine the stage at which change occurred. ${ }^{69}$

\section{What Prompted the Change?}

We identified three reasons for change in the NRS from what the Royal Commission had recommended: economics, politics, and convenience of the operator. Table 1 (column 5) shows the pressure points for each matter of contention. Of 14 matters with change: seven may be attributed to economics, three to politics, and four to scheme operator convenience. ${ }^{70} \mathrm{We}$ recognise that economics and politics are intertwined, but our aim was to determine which one likely had precedence. We did not have access to confidential materials and thus provide a broad-brush analysis with reference to information in the public domain, for example, press releases, media interviews with government officials, and Department of Social Services ('DSS') submissions to parliamentary committees.

By economics, we mean any monetary costs of the scheme for government and non-government institutions. A Finity Consulting Report estimated that the total cost of the scheme, if governments were funders of last resort, would be roughly

65 Reduced monetary payment cap, single application, timeframe for institutions to opt in, citizenship/residency eligibility requirement, and funder of last resort.

66 Direct personal response and deed of release.

67 Criminal history exclusion and acceptance period.

68 No application from gaol and minimum age at application.

69 Counselling and psychological care, the Assessment Framework, and scheme reporting.

70 Our categorisation may be challenged, particularly for economics. For example, we cannot be sure why the Direct Personal Response underwent significant change in the NRS: might this have been caused by institutions that did not wish to engage directly with survivors, as much as by economics? Likewise, we cannot be sure why the NRS restricted the age eligibility of applicants: might this have been caused more by politics than by economics? 
similar for government (47\%) and non-government (53\%) institutions. ${ }^{71}$ We do not know what role non-government organisations played in negotiating the economic costs for the scheme, but because their contributions were estimated by Finity to be substantial, the economics at play were (and are) not just a matter for governments.

By politics, we mean any political costs of the scheme to governments (such as loss of votes or public support) caused by 'bad press' or a perceived failure to pass the 'pub test'. ${ }^{72}$ There may have been political costs to non-government institutions, but if there were, it was not apparent in remarks made by government officials.

By operator convenience, we mean any perceived administrative costs to implementing the scheme.

\section{The Five Headliners}

The five headliners have saturated discussion and debate on redress legislation in parliamentary materials and the media. What has caused these matters to take centre stage? A unifying feature is that all five have clear and tangible consequences for survivors. Critique has centred on their lowered funding support and value judgements about who is more or less 'deserving' of redress. From the perspective of survivors and advocates, two scheme elements are less generous than that recommended by the Royal Commission (the monetary payment cap and counselling and psychological care). Two purposely or negligently exclude certain individuals and types of abuse (criminal history exclusion and redress for sexual abuse only), and one does not reflect survivors' living experience of abuse (the Assessment Framework). Advocacy groups, such as care leaver organisations and counselling support services, have also been vigilant in raising matters that affect their client base.

\section{Monetary Payment Cap}

Under the NRS, the monetary payment maximum is $\$ 150,000$, which is $\$ 50,000$ less than what the Royal Commission had recommended.

The Royal Commission said that ' $[\mathrm{t}]$ he purpose of a monetary payment under redress should be to provide a tangible recognition of the seriousness of the hurt and injury suffered by a survivor' ${ }^{73}$ The payment is one of three redress elements

71 Finity Consulting, National Redress Scheme Participant and Cost Estimates: Royal Commission into Institutional Responses to Child Sexual Abuse (Report, July 2015) 64.

72 For instance, if a well-known person who was imprisoned for committing criminal acts, including sexual crime, applied to the scheme, or if Australian non-residents or non-citizens could apply for monetary payments.

73 Redress and Civil Litigation Report (n 11) 20. Its explanation of the purpose of monetary payments closely echoes that of the architects of the Irish Residential Institutions Redress Scheme: '[T]he award of appropriate financial redress can at least provide some tangible recognition of the seriousness of the hurt and injury which has been caused to the victims of institutional child abuse': Compensation Advisory Committee, Towards Redress and Recovery (Report to the Minister for Education and Science, January 2002) 66 . 
that the Royal Commission recommended. ${ }^{74}$ It was listed in third position in the Commission's discussion of redress, behind the direct personal response (in first position) and counselling and psychological care (second position). By contrast, the CRS and NRS both prioritised the monetary payment over the other elements. ${ }^{75}$

Although the Royal Commission recommended 'a maximum payment of $\$ 200,000$ ' for the 'most severe' cases of abuse, ${ }^{76}$ Brandis and Porter announced in November 2016 that the CRS maximum would be $\$ 150,000$. Porter gave reasons for the reduction in a press conference:

[W]e have had intensive negotiations with the states and territories, and with churches and charities. And we were trying to design a monetary redress payment that offered appropriate recognition, but maximised our opportunity to get other organisations to opt-in to the scheme. ${ }^{77}$

Ensuing public debate about the government's reduction of the maximum to $\$ 150,000$ has unduly emphasised the monetary payment as the most significant element of redress. ${ }^{78}$ Furthermore, the sole focus on the maximum amount has blinded most commentary. To be sure, a maximum has 'symbolic value', ${ }^{79}$ and this ignites public debate. However, when comparing redress payments, one must examine the minimum and maximum, the 'spread' (distribution of payments), and the average. The average payment is a more meaningful yardstick than the maximum, and it should have been the focal point of debate. Some redress schemes have high maxima, but their average payments are relatively low. ${ }^{80}$

The reduced maximum payment has been criticised by survivors and their supporters, many of whom continue to advocate for the adoption of the Royal

74 Redress and Civil Litigation Report (n 11) 9 (Recommendation 2).

75 Commonwealth Redress Scheme for Institutional Child Sexual Abuse Bill 2017 (Cth) s 18(1) ('CRS Bill'); NRS Act s 16(1).

76 Redress and Civil Litigation Report (n 11) 24 (Recommendation 19(b)).

77 Christian Porter, 'National Redress Scheme' (Press Conference, Department of Social Services, 4 November 2016).

78 Indeed, the shorthand meaning and usage of 'redress' by survivors, advocates, and others is restricted to money alone. Redress, like reparation, is more encompassing: see Daly, Redressing Institutional Abuse of Children (n 51) 115.

79 Kathleen Daly, Submission No 49 to Joint Select Committee on Oversight of the Implementation of Redress Related Recommendations of the Royal Commission into Institutional Responses to Child Sexual Abuse (21 November 2018) 3. Daly argued that data on payments should be monitored to determine if the $\$ 76,000$ average that the DSS estimated was, in fact, being achieved: Department of Social Services, Submission No 27 to Senate Standing Committee on Community Affairs (n 40) 1.

80 In an updated analysis of 45 individualised schemes, we show that the maxima range from $\$ 14,700$ to $\$ 441,000$. Of $45,11(24 \%)$ have maxima of $\$ 147,000$ or greater. Of these, five are Australian (the NRS and four non-government schemes at $\$ 150,000$ ). Excluding two outliers (maxima greater than $\$ 400,000$ ), the average maxima for 43 schemes is $\$ 76,700$. The average payment for individualised schemes for which there is data $(n=36)$ is $\$ 38,300$. The five top average payments range from $\$ 71,000$ to $\$ 96,802$. These figures are not adjusted for inflation, but suggest that a maximum payment of $\$ 150,000$ and an average payment of $\$ 76,000$ (as estimated by DSS for the NRS: see above $n$ 79) would place the NRS among the five top individualised schemes in the world with respect to both the maximum and average payment. See Kathleen Daly and Juliet Davis, 'Mapping the World of Redress for Institutional Abuse' (Conference Paper, Society for the History of Children and Youth, 26 June 2019) (copy on file with authors). 
Commission's level of payment. ${ }^{81}$ Despite this, the maximum remained at $\$ 150,000$ when the CRS shifted to the NRS. ${ }^{82}$

The secrecy surrounding the decision to reduce the maximum payment has also been a source of frustration and speculation. As then Senator Hinch complained: 'I am chair of this bloody [Joint Select] committee and, in recent months, I've been unable to find out not only who suggested the $150 \mathrm{~K}$ but also who lobbied for it and who signed off on it' ${ }^{83}$ Prominent advocate Chrissie Foster gave evidence to the Senate Community Affairs Legislation Committee ('Senate Committee') on 6 March 2018, in which she claimed that the maximum monetary payment was 'reduced from $\$ 200,000$ to $\$ 150,000 \ldots$ because the Department of Social Services was in workshops with the churches and decided to reduce the redress payment ...' ${ }^{84}$ This was denied by Francis Sullivan, then chief executive of the Catholic Church's Truth Justice and Healing Council, who told the Senate Committee that he had 'no idea how the government of the day made its mind up about $\$ 150,000$. We weren't part of any of those conversations. It was a government policy' ${ }^{\prime}{ }^{5}$ During debates on the NRS Bill, Senator Fierravanti-Wells repeatedly said that the reduction was based on agreements between 'state and territory governments, the Commonwealth and non-government institutions' ${ }^{86}$ The lack of public information about the role and influence of responsible institutions in setting the maximum has raised suspicions that institutional 'low cost' interests prevailed.

\section{Criminal History Exclusion}

The Royal Commission's recommendations were silent about applicants' criminal histories.$^{87}$ This later became an eligibility factor under the CRS and NRS.

The strictest iteration of the exclusion was proposed in the CRS. The CRS Bill did not contain an express provision that excluded an applicant from redress based on their criminal history; however, it did allow for rules to prescribe whether a person would be 'not eligible for redress under the scheme' ${ }^{.8}$ An ABC interview with Christian Porter, then Minister for Social Services, on 26 October 2017 revealed that survivors would not be eligible for redress under the CRS if they had

81 See, eg, Chrissie Foster, Submission No 15 to Senate Standing Committee on Community Affairs, Parliament of Australia, Commonwealth Redress Scheme for Institutional Child Sexual Abuse Bill 2017 and Related Bill.

82 NRS Act s 16(1)(a).

83 Commonwealth, Parliamentary Debates, Senate, 18 June 2018, 3042 (Derryn Hinch).

84 Evidence to Senate Community Affairs Legislation Committee on the Inquiry into the Commonwealth Redress Scheme for Institutional Child Sexual Abuse Bill 2017, Commonwealth Redress Scheme for Institutional Child Sexual Abuse (Consequential Amendments) Bill 2017, Parliament of Australia, Melbourne, 6 March 2018, 35 (Chrissie Foster).

85 Evidence to Senate Community Affairs Legislation Committee on the Inquiry into the Commonwealth Redress Scheme for Institutional Child Sexual Abuse Bill 2017, Commonwealth Redress Scheme for Institutional Child Sexual Abuse (Consequential Amendments) Bill 2017, Parliament of Australia, Melbourne, 6 March 2018, 60 (Francis Sullivan, Chief Executive Officer, Truth, Justice and Healing Council).

86 Commonwealth, Parliamentary Debates, Senate, 18 June 2018, 3162 (Concetta Anna Fierravanti-Wells).

87 Redress and Civil Litigation Report (n 11) 355 (Recommendations 43, 47).

88 CRS Bill s 16(3). 
been convicted of any sexual offence or a serious crime ${ }^{89}$ DSS later explained that a serious crime included 'serious drug, homicide or fraud offences for which [a survivor] received a custodial sentence [to serve] of five or more years'.$^{90}$ Thus, under the CRS, the criminal history exclusion distinguished between any type of sexual offence and other serious offences. A conviction for any sexual offence would render an applicant ineligible. For non-sexual offences, eligibility rested on the seriousness of the offence as determined by the incarceration period.

In the $\mathrm{ABC}$ interview, Minister Porter said that the decision to implement the exclusion was made in 'deep consultation' with state Attorneys-General, who were of the 'almost unanimous' view that in order to 'give integrity and public confidence to the scheme, there had to be some limitations for applications from people who themselves had committed serious crimes, but particularly sexual offences' ${ }^{91}$ Porter claimed that state Attorneys-General put forward this limitation as a necessary 'part of the framework to get them potentially to opt in', which served as a 'powerful reason' why the Commonwealth decided to include it. ${ }^{92}$ State and territory ministers were also said to be 'of the strong view that excluding some people based on serious criminal offences is necessary to ensure the scheme is not using taxpayer money to pay redress to those whose actions may not meet prevailing community standards'. ${ }^{93}$

The criminal history exclusion was loosened in the transition to the NRS. Attorney-General for Western Australia, John Quigley, said that the state had sought a 'fairer and more equitable' discretionary approach towards applicants with serious criminal histories when negotiating to join the scheme. ${ }^{94}$ Under the NRS, a person would be ineligible for redress if "before or after making the application, the person is sentenced to imprisonment for five years or longer for an offence against a law of the Commonwealth, a State, a Territory or a foreign country'.$^{95}$ Notably, a sexual offence alone is not a disqualifying factor; rather the length of an incarceration term is decisive. Under the NRS, an applicant with a 'serious criminal conviction' will undergo a 'special assessment' process in which the scheme operator will consider various factors including: 'the nature of the offence ... length of the sentence of imprisonment ... and any rehabilitation of the person'. ${ }^{96}$ A person may be eligible for redress if the operator is 'satisfied' that this 'would not bring the scheme into disrepute; or adversely affect public confidence in, or support for, the scheme'. ${ }^{97}$

89 Interview with Christian Porter (Sabra Lane, ABC Radio National, 26 October 2017)

$<$ https://formerministers.dss.gov.au/17295/abc-radio-national-redress-minister-cash/>.

90 Department of Social Services, Submission No 27 to Senate Standing Committee on Community Affairs (n 40) 4.

91 Interview with Christian Porter (n 89).

92 Ibid.

93 Department of Social Services, Submission No 27 to Senate Standing Committee on Community Affairs (n 40) 4.

94 Victoria Laurie, 'Abuse Redress Scheme Locked in as Western Australia Signs On', The Australian (online, 28 June 2018) <https://www.theaustralian.com.au/national-affairs/state-politics/abuse-redressscheme-locked-in-as-western-australia-signs-on/news-story/05a0494e8437947c49ec0e9b6a2ab19c >. NRS Act s 63(1).

96 Ibid s 63(6).

97 Ibid s 63(5). 


\section{Eligible Abuse}

The restriction of redress to victims of sexual abuse has remained consistent throughout the scheme's evolution. This has been a significant source of critique, particularly among care leaver advocacy groups.

In its redress report, the Royal Commission recognised that ' $[\mathrm{m}]$ ost previous and current redress schemes cover at least sexual and physical abuse. Some also cover emotional abuse or neglect'. ${ }^{98}$ However, it did 'not accept' that its Letters Patent allowed it 'to consider redress for those who have suffered physical abuse or neglect, or emotional or cultural abuse, if they have not also suffered child sexual abuse in an institutional context' ${ }^{99}$ Similarly, the CRS Bill and the NRS Act state that a survivor of institutional abuse would only be eligible for redress if he or she were 'sexually abused'. ${ }^{100}$

While the presence of sexual abuse is a threshold criterion, other forms of mistreatment may be considered in determining the monetary payment. The Senate Committee, which examined the CRS and NRS Bills, was aware of the impact of other forms of abuse or neglect on survivors. ${ }^{101}$ During the March 2018 hearing of the Senate Committee, then Senator Hinch apologised to care leavers who were present at the hearing for having been 'totally focused, with the blinkers on, on victims of ... sexual assault'. ${ }^{102}$ Despite Hinch's interest in widening the scope of abuse, the government confirmed that its assessment framework would only include forms of non-sexual abuse if sexual abuse was also present. ${ }^{103}$ Under the NRS, non-sexual abuse may include psychological abuse, physical abuse, and neglect. ${ }^{104}$

\section{Counselling and Psychological Care}

The NRS has restricted the counselling and psychological care recommended by the Royal Commission in terms of its amount, duration, and eligibility.

The Royal Commission cited access to counselling and psychological care as a key element of redress for survivors. ${ }^{105}$ It recommended that there be 'no fixed

98 Redress and Civil Litigation Report (n 11) 100.

99 Ibid 6

100 CRS Bill s 16(1)(a); NRS Act s 13(1)(a).

101 Redress and Civil Litigation Report (n 11) 102; Senate Community Affairs Legislation Committee, Parliament of Australia, Report on Commonwealth Redress Scheme for Institutional Child Sexual Abuse Bill 2017 and Commonwealth Redress Scheme for Institutional Child Sexual Abuse (Consequential Amendments) Bill 2017 (Report, March 2018) 93 ('Senate Community Affairs Legislation Committee, CRS Report').

102 Evidence to Senate Community Affairs Legislation Committee on the Inquiry into the Commonwealth Redress Scheme for Institutional Child Sexual Abuse Bill 2017, Commonwealth Redress Scheme for Institutional Child Sexual Abuse (Consequential Amendments) Bill 2017, Parliament of Australia, Melbourne, 6 March 2018, 22 (Derryn Hinch).

103 Parliament of Australia, 'Australian Government Response to the Senate Committee Affairs Legislation Committee Report: Inquiry into the Commonwealth Redress Scheme for Institutional Child Sexual Abuse Bill 2017 [Provisions] and the Commonwealth Redress Scheme for Institutional Child Sexual Abuse (Consequential Amendments) Bill 2017 [Provisions]' (Report, 29 May 2018) 5.

104 NRS Act $\mathrm{s} 6$.

105 Redress and Civil Litigation Report (n 11) 9 (Recommendation 2). 
limits on the counselling and psychological care provided to a survivor' and that a survivor's family members should also be provided with counselling and psychological care, 'if necessary for the survivor's treatment'. ${ }^{106}$

The CRS Bill included counselling and psychological care as an element of redress. ${ }^{107}$ However, it did not say how such services were to be provided and left this to be prescribed by the Minister under the scheme's rules. ${ }^{108}$ These rules were never released; however, at a press conference on 4 November 2016, then Minister for Social Services Christian Porter declared that 'the Commonwealth scheme will ... provide for access for survivors to trauma-informed and culturally-adapted counselling over the entire life of the scheme'. ${ }^{109}$ The CRS Bill's Explanatory Memorandum also said that '[s]ubclause 49(1) [of the CRS Bill] provides that counselling and psychological services should be available throughout the life of the Scheme'. ${ }^{110}$ The CRS Bill, as introduced, did not contain this subclause. However, these statements suggest that counselling and psychological services under the CRS were likely to be limited to the life of the scheme, contrary to the Royal Commission's recommendations. In his October 2017 ABC radio interview on the day the CRS was introduced into Parliament, ${ }^{111}$ Porter made the surprising announcement that payments for counselling services would be capped at $\$ 5,000$ under the CRS, and that counselling would not be offered to family members of survivors. ${ }^{112}$

These proposed limits were later embedded in the NRS. The NRS Act provides that a successful applicant will be eligible for a 'counselling and psychological component' ('CPC') that consists of either access to state or territory services provided under the scheme or a lump sum that will allow a claimant to access CPC services privately. ${ }^{113}$ Each state and territory can decide whether survivors in their jurisdiction will receive a lump payment or access to available services. ${ }^{114}$ For example, the Victorian government has established Restore, a counselling service for Victorian residents who have accepted an offer under the redress scheme. ${ }^{115}$ Users of this service are entitled to a minimum of ' 20 hours of counselling and/or Aboriginal healing at any time over the course of their lifetime'. ${ }^{116}$

106 Ibid 63.

107 CRS Bill s 18(1)(b).

108 Ibid s 48.

109 Christian Porter, 'National Redress Scheme' (Press Conference, Australian Government, 4 November 2016).

110 Explanatory Memorandum, Commonwealth Redress Scheme for Institutional Child Sexual Abuse Bill 2017, Commonwealth Redress Scheme for Institutional Child Sexual Abuse (Consequential Amendments) Bill 2017 (Cth) 31 ('Explanatory Memorandum, CRS Bill').

111 Interview with Christian Porter (n 89).

112 Ibid.

113 NRS Act s 16(1)(b); Commonwealth, Parliamentary Debates, House of Representatives, 10 May 2018, 3634 (Dan Tehan).

114 Commonwealth, Parliamentary Debates, House of Representatives, 10 May 2018, 3634 (Dan Tehan).

115 Department of Health and Human Services (Vic), Restore - Victorian Redress Counselling Service Frequently Asked Questions (August 2019) $1<\mathrm{https}$ ://services.dhhs.vic.gov.au/restore-victorian-redresscounselling-service-questions-and-answers $>$.

116 Department of Health and Human Services (Vic), Program Requirements for the National Redress Scheme Counselling Service in Victoria (April 2019) 9. 
The NRS Act limits the maximum CPC to $\$ 5,000$, regardless of the number of responsible institutions involved. ${ }^{117}$ The Assessment Framework, which was tabled in Parliament on 13 August 2018 (see below Part III(D)(5)) imposes further limits by tying the amount of the CPC to the kind of sexual abuse experienced by an applicant. Under the Assessment Framework, a person who has experienced penetrative abuse is entitled to a maximum of $\$ 5,000$ in CPC, but the amount for a person who has undergone contact abuse or exposure abuse is capped at $\$ 2,500$ and $\$ 1,250$, respectively. ${ }^{118}$ The CPC does not extend to survivors' family members, nor is it available to a survivor's estate in the case of death. ${ }^{119}$

\section{Assessment Framework}

The NRS Assessment Framework has been criticised for its rigid method of assessing survivors' claims and the ambiguity that surrounds its implementation. It privileges penetrative abuse above all other types of sexual abuse, and it caps monetary and counselling payments based on the type of abuse.

The Royal Commission recommended the use of a matrix to assess redress claims, prioritising 'the need for fairness, equality and transparency for survivors - and ... institutions' over an 'individualised approach'. ${ }^{120}$ This matrix would determine the monetary amount payable for each claim by giving it a score out of 100 points, with 40 points allocated to the 'severity of abuse', 40 points to the 'impact of abuse', and 20 points to 'additional elements'. ${ }^{121}$ These 'additional elements' were intended to recognise whether, at the time of the abuse, 'the applicant was in state care ... experienced other forms of abuse in conjunction with the sexual abuse ... was in a "closed" institution or without the support of family or friends ... [or] was particularly vulnerable to abuse because of his or her disability'. ${ }^{122}$

The Royal Commission recognised in its Final Report that '[m]any complex and interconnected factors can influence the way that victims are affected by child sexual abuse', including 'the characteristics of the abuse (such as the type, duration and frequency); the relationship of the perpetrator to the child; the social, historical and institutional contexts of the abuse; [and] the victim's circumstances, experiences and characteristics (such as age, gender, disability, prior maltreatment, and experiences with disclosing the abuse)'. ${ }^{123}$ The way in which an institution responded to child abuse was also found to significantly affect a survivor. ${ }^{124}$

117 NRS Act s 16(b)(ii); Explanatory Memorandum, NRS Bill (n 41$) 37$.

118 Assessment Framework s 6.

119 Explanatory Memorandum, NRS Bill (n 41) 9.

120 Redress and Civil Litigation Report (n 11) 21. To clarify, using a matrix to determine monetary payments for a large group of survivors does assess each individual against a particular set of criteria and thus, it is an individualised assessment. What the Royal Commission is referring to is a "detailed and individualised assessment of [a survivor's] experiences and the damage they have suffered' without reference to a common set of criteria: at 234 . Ibid 22 (Recommendation 16).

22 (Recommendation 17)

123 Final Report (n 6) vol 3, 10.

124 Ibid vol 3,11. There is a substantial body of literature regarding the consequential harms arising from child sexual abuse: for an overview see Ben Mathews, 'A Taxonomy of Duties to Report Child Sexual 
The CRS Bill said that the Commonwealth's assessment matrix would be declared by the Minister. ${ }^{125}$ However, this matrix was never released. Similarly, the NRS Assessment Framework was contained in delegated legislation, which was tabled months after the scheme's commencement, on 13 August 2018. ${ }^{126}$

The Assessment Framework ties the redress payment to the kind of abuse experienced, establishing a hierarchy of abuse in which penetrative abuse is recognised as a more serious form of sexual abuse than contact or exposure abuse. ${ }^{127}$ A survivor who experienced penetrative abuse can receive a flat ${ }^{128}$ payment of $\$ 70,000$, while flat payments for contact abuse and exposure abuse are $\$ 30,000$ and $\$ 5,000$, respectively. The impact of sexual abuse is also predetermined by the type of abuse suffered and does not take into account frequency or duration. ${ }^{129}$ The impact of penetrative abuse can be awarded a flat figure of $\$ 20,000$, while flat figures for contact abuse and exposure abuse are $\$ 10,000$ and $\$ 5,000$, respectively.

If a survivor experienced 'related non-sexual abuse' as well as any form of sexual abuse, they can receive a flat payment of $\$ 5,000$. In addition, a survivor is eligible to receive a flat payment of $\$ 5,000$ if they were 'institutionally vulnerable', that is, if the risk of sexual abuse was increased by their 'living arrangements' ${ }^{130}$ These payments do not vary depending on the kind of sexual abuse.

An additional flat payment of $\$ 50,000$ can be awarded to survivors who suffered sexual abuse in 'extreme circumstances', that is, when the abuse was penetrative and it is 'reasonable to conclude that [it] was so egregious, long-term or disabling to the person as to be particularly severe' when 'taking into account whether the person was institutionally vulnerable and whether there was related non-sexual abuse'. ${ }^{131}$ The Assessment Framework does not provide 'recognition of extreme circumstances' payments for non-penetrative abuse. Therefore, the maximum payment for penetrative abuse is $\$ 150,000$, but survivors of contact abuse and exposure abuse can receive maximum payments of $\$ 50,000$ and $\$ 20,000$, respectively.

'Independent decision-makers' ${ }^{132}$ determine claims for redress using the 'assessment framework policy guidelines' ${ }^{133}$ These guidelines provide additional information and examples of how a decision-maker should apply the Assessment

Abuse: Legal Developments Offer New Ways to Facilitate Disclosure' (2019) 88 (February) Child Abuse \& Neglect 337.

125 CRS Bill s 34.

126 NRS Act s 32.

127 Assessment Framework s 5.

128 By 'flat' we mean an 'all or nothing' payment, as compared to a maximum payment.

129 knowmore, Submission No 31 to the Joint Select Committee on Oversight of the Implementation of Redress Related Recommendations of the Royal Commission into Institutional Responses to Child Sexual Abuse (August 2018) 6.

130 Explanatory Statement, National Redress Scheme for Institutional Child Sexual Abuse Assessment Framework 2018.

131 Assessment Framework s 4.

132 Department of Social Services (Cth), Guides to Social Policy Law: National Redress Guide (version 1.03, 1 July 2019) 1.1.O.10.

133 Ibid 6.6. 
Framework to a range of varied circumstances. ${ }^{134}$ The guidelines are not a legislative instrument and are not publicly available. ${ }^{135}$ Any unauthorised person who 'obtains, makes a record of, discloses or uses information that is contained in the assessment framework policy' commits an offence and may be imprisoned for two years or fined 120 penalty units $(\$ 25,200) .{ }^{136}$ This secrecy is justified on the grounds that disclosing the guidelines would 'enable people to understand how payments are attributed and calculated, and risks the possibility of fraudulent or enhanced applications designed to receive the maximum redress payment under the Scheme'. ${ }^{137}$ However, the lack of clarity surrounding the Assessment Framework has complicated the assessment process for prospective claimants and their supporters. In particular, representatives from the free legal service for survivors, knowmore, have urgently sought guidance about what information is needed in order to meet the 'extreme circumstances' criteria and receive an additional $\$ 50,000 .{ }^{138}$

\section{E The Twelve Buried Leads}

The term 'buried leads' draws on newspaper jargon to describe 12 matters of contention that have been overshadowed by the headliners. These matters have important consequences for the level of engagement that a survivor can request from an institution (direct personal response), scheme coverage (timeframe for institutions to opt in and funder of last resort), the application process (single application, indexation of payment, acceptance period, and deed of release), other eligibility requirements (no application from gaol, citizenship or residency, and minimum age limit), and scheme oversight (lack of external review and scheme reporting). So why have they been overlooked?

The salience of these matters may be difficult to grasp for the media or members of the public. Some operate in a manner that is seemingly more technical and nebulous than the headliners. One example is the intersection between the single application and the opt in timeframe. Others are the reduced scope for funder of last resort, the indexation of payments, and the wider range of entities covered by the deed of release. Barriers introduced to applicants may appear to be only temporary (no application from gaol and the minimum age limit) or affect those with lower sociopolitical status (citizenship or residency requirements). Other matters will become more apparent in time (lack of external review and reduced scheme reporting). Although we call these buried leads, each was brought forward and considered during the legislative process, and in submissions to and hearings by the Senate Committee and Joint Select Committee. However, they were less prominent, and received less airtime, in public discussion and media reporting.

\footnotetext{
134 Explanatory Statement, National Redress Scheme for Institutional Child Sexual Abuse Assessment Framework 2018.

135 NRS Act s 33(4).

136 NRS Act s 104; Explanatory Memorandum, NRS Bill (n 41) 68.

137 Explanatory Memorandum, NRS Bill (n 41) 38.

138 Evidence to Joint Select Committee (n 46) 10-11 (Anna Swain, knowmore).
} 


\section{Direct Personal Response}

Of all the buried leads, the Direct Personal Response ('DPR') received the least attention and the greatest retraction. Under the CRS and NRS, it was severely weakened. What the Royal Commission had intended for this innovative element was largely eviscerated. Indicative of this shift, when presenting the redress elements in its report, the Royal Commission began with the DPR in first place. ${ }^{139}$ Under the CRS and NRS, it was moved to third place.

As envisaged by the Royal Commission, the DPR had three components: 'an apology', 'an opportunity to meet with a senior representative of the institution', and 'an assurance as to steps taken to protect against further abuse'. ${ }^{140}$ The Royal Commission viewed them as 'essential', and a minimum that every institution should be able to provide to survivors. ${ }^{141}$ The report identifies other activities that could be part of a DPR, including 'assistance with gaining access to records', 'family tracing and family reunion', 'memory projects', 'collective forms of direct personal response such as memorials, reunions and commemorative events', and 'culturally appropriate collective redress for Aboriginal and Torres Strait Island survivors'. ${ }^{142}$ This is what made the DPR a potentially innovative justice mechanism: it could be tailored to what mattered to individuals and groups of survivors. Direct and meaningful institutional offerings, along with familial and collective activities, can create and symbolise a wider set of meanings for redress. The Royal Commission's larger ambition for the DPR was never realised in legislation.

Under the CRS Bill, the DPR requirements were significantly weakened. It was no longer 'essential' that a participating institution provide a DPR. Instead, taking 'reasonable steps' to provide a DPR was sufficient. ${ }^{143}$ What would be offered as a DPR hinged on what participating institutions were 'willing to offer and provide', rather than survivors' wishes. ${ }^{144}$ The apology component was diluted: a statement of acknowledgement or regret would suffice. ${ }^{145}$ The timeframe, manner, and form of the DPR were to be prescribed in the CRS rules; however, these were not released. ${ }^{146}$

Under the NRS, the DPR was further depleted. In addition to incorporating many of the CRS changes noted above, ${ }^{147}$ the NRS Act stipulated that an institution was not required to provide a survivor with all three components of the DPR. Rather, 'any one or more' was acceptable. ${ }^{148}$ It is the responsibility of a survivor to contact the institution to start the DPR process; however, the responsible institution can select the method/s of the DPR it is 'able to use', such as a face-to-face meeting

\footnotetext{
139 Redress and Civil Litigation Report (n 11) 9 (Recommendation 2).

140 Ibid 11.

141 Ibid.

142 Ibid

143 CRS Bill s 50.

144 Ibid s 52(2).

145 Ibid s 52(3)(a).

146 Ibid s 51.

147 NRS Act ss 54(1) ('reasonable steps'), 54(2)(a) (apology element).

148 Ibid s 54(2).
} 
or a letter, and inform the survivor accordingly. ${ }^{149}$ Survivor complaints arising from the DPR process are to be dealt with internally by the participating institution and do not need to be reported to the scheme operator. ${ }^{150}$

\section{Scheme Coverage}

Changes to the timeframe for institutions to opt in and the identification of the 'funder of last resort' have reduced the scheme's coverage by placing greater power in the hands of government and non-government institutions to determine when, and in what capacity, they will be subject to the scheme.

The Royal Commission did not specify an opt in date for institutions; however, it indicated that all participating institutions would be expected to join the redress scheme by its commencement date. ${ }^{151}$ Under both the CRS Bill and the NRS Act, an eligible institution has two years to join the scheme from the date of commencement. ${ }^{152}$ The policy behind 'the longer time period was for the smaller institutions to get their processes in place. It was never envisaged as a slowdown process or a delay tactic, and yet that is in fact what appears to be happening'. ${ }^{153}$ The opt in period has granted non-government institutions, including large religious and charitable institutions, additional flexibility and bargaining power when relating to the scheme. Conversely, it has diminished survivors' capacity to make complete and timely claims against all of the institutions they claim are responsible for their abuse.

Likewise, changes to the 'funder of last resort' principle may diminish the capacity of survivors to receive redress elements when responsible institutions are defunct. The Royal Commission recommended that the "Australian Government and state and territory governments provide "funder of last resort" funding for the redress scheme ... so that the governments would meet any shortfall in funding for the scheme'. ${ }^{154}$ The Royal Commission assumed that state and territory governments would each contribute a share into a common fund. ${ }^{155}$ Thus, governments would cover the monetary payment, CPC, and associated scheme administration costs of a survivor who experienced abuse in an institution that no longer existed or was insolvent. The governments did not need to be responsible for the abuse.

By conceptualising the funder of last resort principle in this manner, the Royal Commission moved beyond a 'responsible entity pays' principle to assert a broader role for governments in providing redress. It claimed that although the primary

149 National Redress Scheme for Institutional Child Sexual Abuse Direct Personal Response Framework 2018 (Cth) ss 5(b), 7.

150 Ibid s 16(1).

151 Recommendation 31 states that ' $[\mathrm{w}]$ hether there is a single national redress scheme or separate state and territory redress schemes, the scheme or schemes should be established and ready to begin inviting and accepting applications from survivors by no later than 1 July 2017': Final Report (n 6) recommendations, 79. This may be construed as intending that all participating institutions would be expected to join the redress scheme by its commencement date, and not permitting an additional two years to do so.

152 CRS Bill s 27(1); NRS Act s 115(4).

153 Evidence to Joint Select Committee (n 46) 20 (Ann Sudmalis).

154 Redress and Civil Litigation Report (n 11) 34 (Recommendation 36).

155 Ibid 34 (Recommendation 37). 
culpability for abuse rested with the abuser and responsible institution, it could not 'avoid the conclusion that the problems faced by many people who have been abused are the responsibility of our entire society'. ${ }^{156}$ As a result, ' $[t]$ he community is entitled to look to governments to meet an identified community need' ${ }^{157}$ Although it did not explicitly say so, the Royal Commission's conceptualisation of the funder of last resort principle rested on assumptions of distributive justice, namely that the benefits and hardships of communal living should be distributed equitably. ${ }^{158}$ Put another way, the Commissioners viewed redress of institutional abuse to be, ultimately, a societal responsibility.

The CRS and NRS define the funder of last resort in a far narrower manner. Each scheme requires that a government acting as funder of last resort bears some responsibility for the abuse; however, the degree of responsibility is a point of difference. The CRS Bill empowered the Commonwealth or territory to act as funder of last resort for a survivor who was abused in a defunct non-government institution of a territory, if the government had 'shared responsibility' for the abuse. ${ }^{159}$ Under the NRS, a government institution (federal, state, or territory) will fund redress to a survivor who was abused in a defunct non-government institution within its jurisdiction, if the government institution is 'equally responsible' for the abuse. ${ }^{160}$ For both schemes, the reduced scope of the funder of last resort principle is a seismic shift from the Royal Commission's conceptualisation of the role of governments in the scheme. It has removed any perception that governments are acting for the broader social good, and instead, limits their role to that of a perpetrator atoning for its past harms. Apart from the ethical questions raised, this change has significant practical implications for survivors when applying to the scheme.

\section{Application Process}

Changes to the application process may bar survivors' attempts to establish a satisfactory and successful redress claim.

Some of these changes limit a survivor's flexibility in making a claim. Under the NRS, and the CRS before it, applicants are allowed to make just one application for redress. ${ }^{161}$ This restriction was not envisaged in the Royal Commission's recommendations. When coupled with the two-year opt in period for participating institutions, this limitation requires survivors to either make a timely application but miss out on potential redress (monetary payments, CPC, and DPR) from institutions that opt in later, or hold off making an application until all of their

156 Ibid 335.

157 Ibid 339.

158 Ibid. The modern meanings of distributive justice can be applied to many circumstances in which the state recompenses victims of violent crime, terrorism, and detention in war, among others. Redress schemes in which the state pays money to victims of institutional abuse share a similar logic and rationale with these other schemes. For payments to victims of violent crime, see Kathleen Daly, Robyn Holder and Victoria Meyer, The FAVE Project, Financial Assistance, and Victims' Experiences (Technical Report No 6, February 2019) 14.

159 Explanatory Memorandum, CRS Bill (n 110) 38.

160 NRS Act s 29(2)(i)(i); Intergovernmental Agreement (n 36) cl 67.

161 NRS Act s 18; CRS Bill s 30. 
relevant institutions have opted in. The coalescence of these two provisions is likely to have a significant negative impact on survivors who are elderly, ill, or financially insecure.

Another change restricts the time a survivor has to consider their offer of redress. This offer specifies the monetary and CPC amounts that the survivor is entitled to under the scheme. ${ }^{162}$ The Royal Commission recommended that the acceptance period should be open for a year. ${ }^{163}$ This time period was reduced in the CRS Bill to 90 days. ${ }^{164}$ Any person who did not accept an offer within this time frame would be deemed to have declined it, and this would close off any future opportunity to apply to the scheme. ${ }^{165}$ Widespread concerns about the acceptance period's inadequate length ${ }^{166}$ resulted in its increase to six months under the NRS Act. However, the same conditions apply: an offer that is not accepted within this period will be deemed to have been declined, and there is no future opportunity to apply. ${ }^{167}$

Changes to the deed of release have widened the range of people and institutions that a survivor must release from civil liability as a condition of accepting an offer of redress. The Royal Commission and the CRS Bill required survivors to release participating institutions that were responsible for the abuse in their claim. ${ }^{168}$ The NRS Act has expanded the range of parties that must be released from civil liability by the applicant prior to accepting an offer of redress. Under the NRS, applicants who wish to take up their offer of redress must relinquish the prospects of future litigation in respect of their abuse claim against 'all participating institutions that are determined ... to be responsible for the abuse of the period; all participating institutions that are determined ... to be associates of those responsible institutions; and all officials of those responsible institutions and associates (other than an official who is an abuser of the person) '. ${ }^{169}$ Therefore, the deed of release under the NRS inoculates a far wider range of entities from future litigation in return for granting redress.

A feature of the application process that has remained constant over time, despite public critique, is the indexation of past payments. Indexation was first recommended by the Royal Commission and has since been in both the CRS Bill and the NRS Act. ${ }^{170}$ Indexation requires that prior monetary payments made to applicants by a responsible institution will be adjusted for inflation and then deducted from the final payment amount. The indexation of past payments has been criticised by survivor support services and advocates on the ground that it is 'mean-spirited and [punishes] survivors who are often living in financial hardship

162 NRS Act s 39.

163 Redress and Civil Litigation Report (n 11) 42.

164 CRS Bill s 28.

165 Ibid s 42(2).

166 Senate Community Affairs Legislation Committee, CRS Report (n 101) 56.

167 NRS Act ss 40, 45(2).

168 Redress and Civil Litigation Report (n 11) 390 (Recommendation 63); CRS Bill s 40.

169 NRS Act s 42(2)(c).

170 Redress and Civil Litigation Report (n 11) 25 (Recommendation 25); CRS Bill s 33(2); NRS Act s 30(2). 
due to the lifelong impacts of their childhood abuse'. ${ }^{171}$ Advocates also argue that indexation is being inconsistently applied: only past payments will be indexed, but payments under the scheme will not be indexed, despite the likelihood of rising inflation rates during the scheme's lifetime. ${ }^{172}$

\section{Other Eligibility Requirements}

Eligibility requirements have been imposed under the scheme that limit access for prisoners, children, and non-citizens or non-residents.

The Royal Commission did not recommend restricting incarcerated survivors' access to the redress scheme. Indeed, the Commission referred in its Final Report to 'a higher prevalence of offending [among child sexual abuse victims] than for people in the general community'. ${ }^{173}$ Nor was the restriction present in the CRS Bill. However, a person who is in gaol is prevented from applying to the NRS, except in exceptional circumstances. ${ }^{174}$ Such exceptional circumstances include when a claimant has a terminal illness or will not be released from gaol during the life of the scheme. ${ }^{175}$ The operator will generally be required to consult with the Attorneys-General of the states and/or territories where the applicant claims to have suffered abuse and where they are incarcerated (thus, multiple jurisdictions may need to be consulted) before determining whether exceptional circumstances exist. ${ }^{176}$ The stated rationale for this restriction is that 'the Scheme will be unable to deliver appropriate Redress Support Services to incarcerated survivors, ... [and] institutions may not be able to deliver an appropriate direct personal response to a survivor if that survivor is incarcerated'. ${ }^{177}$

The NRS prevents survivors who will not reach the age of 18 before the end of the scheme from applying for redress. ${ }^{178}$ Because the scheme is scheduled to run for 10 years, this means that a child born after 30 June 2010 cannot apply. Unlike an incarcerated survivor, there are no exceptional circumstances. ${ }^{179}$ This minimum age requirement was introduced in the NRS; no age limit was specified in the CRS Bill. Similarly, the Royal Commission said that it could see 'no reason why children could not be accommodated within the structures and approaches ... [recommended] for redress in this report'. ${ }^{180}$

The Royal Commission saw 'no need for any citizenship, residency or other requirements, whether at the time of the abuse or at the time of application for

171 Victorian Aboriginal Child Care Agency, Submission No 26 to Joint Select Committee on the Oversight of the Implementation of Redress Related Recommendations of the Royal Commission into Institutional Responses to Child Sexual Abuse (August 2018) 7.

172 Ibid.

173 Final Report (n 6) vol 3, 144.

174 NRS Act s 20.

175 National Redress Scheme for Institutional Child Sexual Abuse Rules 2018 (Cth) s 14(2) ('NRS Rules').

176 Ibid s 14.

177 Explanatory Memorandum, NRS Bill (n 41) 119.

178 NRS Act s 20.

179 Ibid. When a child born before 1 July 2010 makes an application before their $18^{\text {th }}$ birthday, a special process will be used to determine their application 'as soon as practicable' after they turn 18: NRS Act s 21; NRS Rules (n 175) s 15.

180 Redress and Civil Litigation Report (n 11) 7. 
redress' ${ }^{181}$ In contrast, an applicant's status as an 'Australian citizen or a permanent resident ... at the time the person applies for redress' is a feature of both the CRS Bill and the NRS Act. ${ }^{182}$ Critics of this eligibility criterion have expressed concerns that former child migrants, as well as those who experienced sexual abuse in immigration detention, would be unfairly excluded from seeking redress. ${ }^{183}$ The government defended its exclusion on the grounds that it was intended 'to mitigate the risk of fraudulent claims and maintain the integrity of the scheme'. ${ }^{184}$

\section{Redress Oversight}

Two buried leads (the lack of external review and scheme reporting) are concerned with the level of oversight and accountability afforded under the scheme.

The Royal Commission left it to the government establishing the scheme to determine whether appeal processes and external review were appropriate. ${ }^{185}$ Both the CRS Bill and the NRS Act state that scheme decisions can only be internally reviewed and cannot be subject to external review by the Administrative Appeals Tribunal or by judicial review under the Administrative Decisions (Judicial Review) Act 1977 (Cth). ${ }^{186}$ This exemption was justified on the grounds that 'external review would be overly legalistic, time consuming, expensive and would risk further harm to survivors'. ${ }^{187}$

Scheme reporting is a broader means of ensuring transparency and accountability of the scheme. The Royal Commission recommended that the scheme publish the following data, at least once a year:

[T] he number of applications received; the institutions to which the applications relate; the periods of alleged abuse; the number of applications determined; the outcome of applications; the mean, median and spread of payments offered; the mean, median and spread of time taken to determine the application; the number and outcome of applications for review. ${ }^{188}$

The CRS Bill reduced these requirements considerably, proposing that the scheme provide data annually about participating institutions' compliance with document or information requests, or requests for direct personal responses. ${ }^{189}$ Other annual report requirements were to be 'prescribed by the rules'; however, these rules were never released. ${ }^{190}$

181 Ibid 347.

182 CRS Bill s 16(1)(c); NRS Act s 13(1)(e).

183 Senate Community Affairs Legislation Committee, CRS Report (n 101) 36. There appears to be some ambiguity about the status of child migrants within the scheme. The Explanatory Memorandum to the NRS Bill indicated that groups with certain citizenship statuses, including former child migrants who are no longer residing in Australia, may be able to apply via the scheme rules: Explanatory Memorandum, NRS Bill (n 41) 7-8. The NRS Rules provide for certain child migrants from the United Kingdom and Malta to be able to apply to the scheme: NRS Rules (n 175) s 10.

184 Explanatory Memorandum, NRS Bill (n 41) 20.

185 Redress and Civil Litigation Report (n 11) 383.

186 Explanatory Memorandum, CRS Bill (n 110) 6-7.

187 Ibid 7.

188 Redress and Civil Litigation Report (n 11) 45 (Recommendation 69(e)).

189 CRS Bill s 122.

190 Ibid s 122(4). 
Under the NRS Act, a report on the operation of the scheme must be produced annually by the operator and given to the Minister to present to Parliament. ${ }^{191}$ The NRS Rules prescribe the data that must be reported, ${ }^{192}$ which are more extensive than in the CRS Bill. However, the NRS reporting requirements do not include all the items the Royal Commission recommended. Specifically, the operator is now required to enumerate, but not to name, the institutions that were found to be responsible for abuse. Further, the operator is not required to report on 'the mean, median and spread of time taken to determine the application' and 'the number and outcomes of applications for review' ${ }^{193}$

\section{EVALUATING THE NRS}

\section{A Legislative Change and the Spirit of the Royal Commission}

Redress for institutional abuse has seen profound change from what was envisaged by the Royal Commission to what was legislated in the NRS. How might we evaluate what occurred? During the Senate Committee and Joint Select Committee hearings, a frequent comment was that legislative changes did not reflect 'the spirit' of what the Royal Commission had intended. The term captured a political and moral stance of what redress for institutional abuse could and should be, ${ }^{194}$ just as it was unravelling. The spirit of the Royal Commission can be encapsulated in three of its four principles of redress, set forth in the Redress and Civil Litigation Report:

- 'Redress should be survivor focused';

- 'All redress should be offered, assessed and provided with appropriate regard to what is known about the nature and impact of child sexual abuse - and institutional child sexual abuse in particular - and to the cultural needs of survivors'; and

- 'All redress should be offered, assessed and provided with appropriate regard to the needs of particularly vulnerable survivors. ${ }^{\prime} 195$

We use these principles to evaluate the NRS. We chose not to use the fourth principle, "there should be a "no wrong door" approach for survivors in gaining access to redress'. It called for a flexible approach to assist survivors in understanding and applying for redress, ${ }^{196}$ but did not provide a criterion for evaluating change.

$191 \quad$ NRS Act $\mathrm{s} 187$.

192 NRS Rules (n 175) s 75. The matters that need to be reported annually include the number of people who made redress applications, were deemed eligible, accepted redress offers, and declined redress offers. The operator must also report the number of institutions found responsible for abuse, the range and total of the payment amounts, as well as details relating to the provision of the CPC and DPR.

195 Redress and Civil Litigation Report (n 11) 10 (Recommendation 4).

196 Ibid 133. 
Table 2 lists each matter of contention, and asks whether change in the NRS adhered to each of three Royal Commission redress principles. We faced some difficulties in this exercise. First, of the three principles, 'having regard to the nature and impact of child sexual abuse' was difficult to code for each matter. For some, there may have been an indirect relationship, but we coded only for those that had a clear relationship, based on the research literature. When this was not possible, it was coded as 'no clear relationship' ('NCR') between the matter and the redress principle in the research literature. Second and relatedly, NRS departures from the redress principles may lightly touch upon a number of them, but here too we coded them as NCR. For example, the erosion of the apology element in the DPR may be seen as failing to have regard to the needs of particularly vulnerable survivors (Table 2 , column 4) because an 'apology' versus a 'statement of regret' is a sensitive matter for many survivors. Thus, our evaluation errs in a conservative direction.

Table 2: Did change in the NRS adhere to the Royal Commission's principles of redress?

\begin{tabular}{|c|c|c|c|}
\hline $\begin{array}{l}\text { Matters of contention } \\
(n=17) \\
\text { (1) }\end{array}$ & $\begin{array}{l}\text { Survivor-focused } \\
\text { (2) }\end{array}$ & $\begin{array}{l}\text { Regard to the nature } \\
\text { and impact of child } \\
\text { sexual abuse } \\
\text { (3) }\end{array}$ & $\begin{array}{l}\text { Regard to the needs } \\
\text { of particularly } \\
\text { vulnerable survivors } \\
\text { (4) }\end{array}$ \\
\hline \multicolumn{4}{|l|}{ A Headliners } \\
\hline Monetary payment cap & no & NCR & NCR \\
\hline Criminal history exclusion & no & no & no \\
\hline Eligible abuse (no change) & NA & NA & NA \\
\hline $\begin{array}{l}\text { Counselling and } \\
\text { psychological care }\end{array}$ & no & no & no \\
\hline Assessment framework & no & no & no \\
\hline \multicolumn{4}{|l|}{ B Buried Leads } \\
\hline \multicolumn{4}{|l|}{ Direct personal response } \\
\hline Direct personal response & no & NCR & NCR \\
\hline \multicolumn{4}{|l|}{ Scheme coverage } \\
\hline $\begin{array}{l}\text { Timeframe for institutions } \\
\text { to opt in }\end{array}$ & no & NCR & no \\
\hline Funder of last resort & no & NCR & NCR \\
\hline
\end{tabular}




\begin{tabular}{|c|c|c|c|}
\hline \multicolumn{4}{|l|}{ Application process } \\
\hline Single application & no & no & no \\
\hline Indexation (no change) & NA & NA & NA \\
\hline Acceptance period & no & no & no \\
\hline Deed of release & no & NCR & NCR \\
\hline \multicolumn{4}{|l|}{ Other eligibility requirements } \\
\hline No application from gaol & no & no & no \\
\hline Citizenship/residency & no & NCR & no \\
\hline Minimum age at application & no & NCR & no \\
\hline \multicolumn{4}{|l|}{ Redress oversight } \\
\hline $\begin{array}{l}\text { Lack of external review (no } \\
\text { change) }\end{array}$ & NA & NA & NA \\
\hline Scheme reporting & no & NCR & NCR \\
\hline
\end{tabular}

$\mathrm{NCR}=$ No clear relationship in the research literature between the matter and the redress principle.

$\mathrm{NA}=$ Not applicable because the matter has not changed from the RC's recommendations to the NRS.

Of 14 matters that saw change, the change did not adhere to:

- being survivor-focused for 14 (column 2);

- having regard to the nature and impact of child sexual abuse for six (column 3); and

- having regard to the needs of particularly vulnerable survivors for nine (column 4).

\section{Survivor-Focused}

The NRS was created from compromise and negotiation: the Federal Government had to encourage state governments and non-government institutions to opt into the scheme. The Federal Government's accommodation may have been based on a premise that greater participation in the scheme would ensure greater access to redress for survivors, but the result was that the scheme increasingly gave way to the interests of participating institutions over those of survivors.

For all 14 contentious matters, none of the legislative changes adhered to the principle of being survivor-focused. Instead, changes placed limits on what was available to survivors (lowering the monetary payment cap, restricting the duration and scope of counselling arrangements, and indexing prior payments). Other changes brought additional barriers to entering the scheme (criminal history 
exclusion, ban on making applications while incarcerated, citizenship of residency requirements, and minimum age limit). The DPR now benefits participating institutions because they are able to choose, albeit in consultation with a survivor, which DPR component(s) they will provide, and they need only show that they have undertaken 'reasonable steps' to provide a response. The changed 'funder of last resort' provisions benefit participating government institutions by limiting their liability to situations where they are equally responsible for abuse. This has reduced the coverage of the scheme and limits survivors' ability to claim for abuse they experienced in defunct institutions. The NRS also requires that survivors give up significant future opportunities for civil litigation by requiring a broader deed of release.

Other changes facilitate scheme operations at the expense of a focus on survivor needs. The two-year opt in deadline for institutions may promote participation, and the single application requirement and the reduced time frame to accept a payment offer may simplify the claims processing procedure. However, the net effect for survivors is that the application process is more uncertain. For example, some may need to delay applying until the institutions responsible for abuse opt in. These administrative procedures do not adequately account for lifelong impacts of child sexual abuse that may hamper a survivor's capacity to apply for and decide about a redress payment in a timely manner, including poor health, alcohol or drug dependency, distrust of authority and fear of institutions, poor educational outcomes, including illiteracy, and housing insecurity. ${ }^{197}$

\section{Regard to the Nature and Impact of Child Sexual Abuse}

The Royal Commission drew upon a wealth of knowledge generated from its round table discussions, hearings, private sessions, reviews of the literature, and commissioned research to develop an understanding of the nature and impact of institutional child sexual abuse. ${ }^{198}$

By contrast, the NRS does not have appropriate regard to research on the impacts of child sexual abuse. The limited funding for counselling and psychological care under the NRS is contrary to the identified need for counselling or psychological services that can be accessed by survivors at key life stages or as a result of external events. ${ }^{199}$ The ban on access to counselling by survivors' family members is concerning in light of research on vicarious trauma arising from abuse. ${ }^{200}$

The significant priority given to penetrative abuse in the Assessment Framework does not reflect research findings that 'penetration is only one of several aspects of abuse that influences the severity of outcomes for victims [and that while] penetration may increase the risk of worse health outcomes, the absence

197 Final Report (n 6) vol 3, 105-55.

198 Ibid vol 2, 9.

199 Antonia Quadara, Mary Stathopoulos and Rachel Carson, Family Relationships and the Disclosure of Institutional Child Sexual Abuse (Report prepared for the Royal Commission into Institutional Responses to Child Sexual Abuse, July 2016) 89. 
of penetration does not mean that a victim suffers lesser impacts'. ${ }^{201}$ The Royal Commission recognised that a range of behaviour constituted child sexual abuse, including penetrative abuse, non-penetrative contact, exposure to sexual acts or materials, and violations of privacy. ${ }^{202}$ The definition of 'sexual abuse' in the NRS Act broadly reflects the Commission's findings. ${ }^{203}$ However, the Assessment Framework fails to operationalise research regarding the defining characteristics of child sexual abuse, ${ }^{204}$ as well as the impact of abuse duration and frequency. ${ }^{205}$ This has been criticised by survivor support services as 'contrary to even the most cursory understanding of child sexual abuse and associated impacts' ${ }^{206}$

The NRS disregards the impact of child sexual abuse, and the redress process, on the lives of survivors. The scheme's single application requirement does not take into account delayed onset of memories and psychological impacts of abuse, which may be triggered by certain events or life stages. ${ }^{207}$ The exclusion of incarcerated survivors and those with serious criminal histories contradicts research findings that prisoners have a 'higher rate of experiences of child sexual abuse' than the general population.208 These exclusions may have a disproportionate impact on Aboriginal and Torres Strait Islander survivors due to the high imprisonment rate of Indigenous people in Australia. ${ }^{209}$

\section{Regard to the Needs of Particularly Vulnerable Survivors}

The Royal Commission emphasised that the redress scheme should consider the needs of particularly vulnerable survivors. However, the scheme has evolved in a manner that chips away at the needs and interests of vulnerable survivors, including care leavers, Aboriginal and Torres Strait Islanders, non-citizens, the elderly, the poor, and the unwell.

The scheme's privileging of sexual, particularly penetrative, abuse, fails to acknowledge the experiences of survivors who were abused in 'closed' institutions and experienced non-sexual abuse or were exposed to a 'sexualised environment'. ${ }^{210}$ The focus on sexual abuse fails to adequately recognise nonsexual harms such as 'deprivation of food and schooling, forced labour and

201 Final Report (n 6) vol 3, 31.

202 Ibid vol 2, 9.

203 NRS Act $\mathrm{s} 6$ states that 'sexual abuse of a person who is a child includes any act which exposes the person to, or involves the person in, sexual processes beyond the person's understanding or contrary to accepted community standards'.

204 For an overview of the literature on defining and understanding child sexual abuse, see Ben Mathews and Delphine Collin-Vézina, 'Child Sexual Abuse: Toward a Conceptual Model and Definition' (2019) 20(2) Trauma, Violence, \& Abuse 131.

205 Assessment Framework s 6.

206 Victorian Aboriginal Child Care Agency (n 171) 8. See also Daly, Submission No 49 to Joint Select Committee on Oversight of the Implementation of Redress Related Recommendations of the Royal Commission into Institutional Responses to Child Sexual Abuse (n 79) 4-5, giving a critical analysis of the Assessment Framework, based on other world redress schemes.

207 Final Report (n 6) vol 3, 26-9; Victorian Aboriginal Child Care Agency (n 171) 12.

208 Final Report (n 6) vol 3, 144.

209 Senate Community Affairs Legislation Committee, CRS Report (n 101) 42.

210 Kathleen Daly, 'Inequalities of Redress: Australia's National Redress Scheme for Institutional Abuse of Children' (2018) 42(2) Journal of Australian Studies 204, 213. 
medical neglect'211 as well as physical abuse. ${ }^{212}$ Excluding survivors who experienced these types of abuse in the absence of sexual abuse has been criticised as 'setting up a hierarchy of suffering which in itself has been traumatic for people who were abused in other ways' ${ }^{213}$ Care leavers argue that they 'were violated in every sense in an institution, and being used sexually was just one of those violations'.$^{214}$

The two-year opt in period for participating institutions, especially when coupled with the single-application requirement, creates disincentives for elderly, poor, or unwell survivors to apply for the maximum monetary payment. The exclusion of incarcerated survivors and survivors with criminal histories further marginalises an already disempowered group and may have a disproportionate impact on Aboriginal and Torres Strait Islander survivors. The requirement that eligible survivors must be citizens or permanent residents excludes immigrants and refugees.

Many scheme restrictions have been justified by policymakers on the basis that they are required to maintain the 'integrity of the scheme'. ${ }^{215}$ However, it appears that the interests of more vulnerable survivors are being abrogated for the putative good of the scheme as a whole. This policy decision is in keeping with Carrabine et al's 'hierarchy of victimisation', which shows how a victim's social status is used to differentiate ideal and non-ideal victims. ${ }^{216}$ Under this formulation, groups that have lower social status or power and are viewed by the majority as being somehow 'troublesome or distasteful' are seen as non-ideal victims and 'have to engage in a struggle to have their experiences taken seriously'. ${ }^{217}$ By establishing provisions that undercut the interests of vulnerable minorities in favour of 'community expectations' ${ }^{218}$ and the 'integrity of the Scheme'219, policymakers have limited the ability of the redress scheme to deliver justice to vulnerable survivors.

211 Frank Golding, Submission No 61 to Royal Commission into Institutional Responses to Child Sexual Abuse, Redress and Civil Litigation (28 February 2015) 2. See Joanna Penglase, Orphans of the Living: Growing up in 'Care' in Twentieth-Century Australia (Fremantle Press, $2^{\text {nd }}$ ed, 2007).

212 Daly, 'Inequalities of Redress: Australia's National Redress Scheme for Institutional Abuse of Children' (n 210) 209.

213 Frank Golding, Submission No 42 to the Senate Community Affairs Legislation Committee, Commonwealth Redress Scheme for Institutional Sexual Abuse Bill 2017 and Related Bill (1 February 2018) 3, cited in Senate Community Affairs Legislation Committee, CRS Report (n 101) 33.

214 Penglase (n 211) 145; Kathleen Daly, 'Abuse in Care Versus Not in Care: We Need to Tackle Potential Bias in a National Redress Scheme', The Conversation (online, 16 February 2018)

$<$ https://theconversation.com/abuse-in-care-versus-not-in-care-we-need-to-tackle-potential-bias-in-anational-redress-scheme-90821>.

215 See, eg, citizenship/residency eligibility requirement: Explanatory Memorandum, NRS Bill (n 41) 117; criminal history exclusion: Interview with Christian Porter (n 89).

216 Carrabine et al, Criminology: A Sociological Introduction (Routledge, $2^{\text {nd }}$ ed, 2009) 161.

217 Ibid.

218 See Explanatory Memorandum, NRS Bill (n 41) 118.

219 Ibid 117. 


\section{$4 \quad$ Whose Interests Prevailed?}

Our analysis of change in the NRS indicates a retreat from the goal of providing justice to survivors in favour of protecting the interests of participating institutions and the scheme operator. None of the changes are survivor-focused. Nearly half the changes are contrary to the Royal Commission's findings regarding the nature and impact of child sexual abuse, including the lifelong, intermittent, and varied impacts of abuse, as well as links between child sexual abuse and future criminal offending. More than half the changes can be expected to disadvantage particularly vulnerable survivors.

Over time, the spirit of the Royal Commission's redress recommendations has been weakened. The NRS is less survivor-focused, trauma-informed, coherent, and responsive to the needs of vulnerable survivors than that originally contemplated by the Royal Commission.

On 2 April 2019, the Joint Select Committee tabled its report on the operation of the redress scheme during its early stages. It made 29 recommendations about a wide range of policy and legislative concerns. For the 17 contentious matters, the Committee recommended:

- increasing the maximum redress payment from $\$ 150,000$ to $\$ 200,000$;

- allowing survivors who are in gaol, or sentenced to five years or more, access to the scheme (unless the operator decides this would bring the scheme into disrepute or undermine public confidence);

- ensuring survivors have access to counselling and psychological care over the course of their lives;

- developing and implementing a new assessment framework;

- encouraging institutional opt in by suspending the charitable status and tax concessions of non-participants;

- removing the 'equal responsibility' requirement from the funder of last resort determination;

- re-considering the practice of indexing past payments;

- allowing certain non-citizens and non-residents access to the scheme; and

- increasing reporting requirements. ${ }^{220}$

It also recommended that a parliamentary committee be formed to oversee the NRS for the life of the scheme. ${ }^{221}$ These recommendations, if implemented, would move the NRS closer to the spirit of the Royal Commission.

\section{WHAT CAN BE DONE?}

There is no such thing as a perfect redress scheme. This is evident in the slim body of research on survivor experiences with schemes, disappointment with

220 Joint Select Committee Final Report (n 4) ix-xiii.

221 Ibid xiii (Recommendation 29). 
outcomes, and critiques of how decisions were made.222 We do not measure the NRS against a yardstick of idealism and perfection. We recognise the difficulties inherent in moving a redress scheme from recommendations to reality. However, as the idea of a national scheme moved from the Royal Commission's recommendations to implementation by federal, state, and territory governments, scheme elements unravelled. The negotiated entry of governments and nongovernment institutions into the scheme led to change that shifted power away from survivors and towards participating institutions. The 'integrity of the scheme' took precedence over survivor-centred principles of redress. In a political sense, it is easy to see why this happened: the federal government was in a weak position and could not (or did not wish to) lead a world-class redress scheme. Rather, it acted more as a coordinator, attempting to find a path through varied interests of governments and institutions, and one that was agreeable to most participants. Although we do not have access to insiders who negotiated the scheme, it appears that least cost and least political damage were the operative principles. We look forward to further analyses that dig deeper into this subject.

The NRS is not, in our view, well placed to ensure justice for survivors, as contemplated in the Royal Commission's terms of reference. Fundamental change is necessary to align the scheme more closely with the informed recommendations of the Royal Commission.

Can we expect to see change? Several observers believed that had Labor won the 2019 federal election, there would have been significant movement to change the NRS. However, the Coalition Government's return to power at the election upended predictions about the scheme's future direction. Since the election, the Minister for Social Services, Anne Ruston, has confirmed that the federal government is considering the recommendations of the Joint Select Committee but also warned that certain changes would need state and territory support.223 Although the scheme is not fixed, any amendment other than 'minor or technical changes' to the NRS Act or NRS Rules must be agreed to by the Ministers' Redress Scheme Governance Board, which is constituted by the Commonwealth, state, and territory ministers responsible for redress. ${ }^{224}$ The voting processes of the Board vary depending on the subject matter. A unanimous vote is required for changes that result in increased costs to participating states and territories or for 'any major change decisions', including 'changes to the maximum redress payment amount',

222 See Daly, Redressing Institutional Abuse of Children (n 51) chs 6-7; Stephen Winter, 'Redressing Historic Abuse in New Zealand: A Comparative Critique' (2018) 70(1) Political Science 1; Sinead Pembroke, 'Historical Institutional Child Abuse in Ireland: Survivor Perspectives on Taking Part in the Commission to Inquire into Child Abuse (CICA) and the Redress Scheme' (2019) 22(1) Contemporary Justice Review 1; Johanna Sköld, Bengt Sandin and Johanna Schiratzki 'Historical Justice Through Redress Schemes? The Practice of Interpreting the Law and Physical Child Abuse in Sweden' (2018) Scandinavian Journal of History 1; Report of Case Study No 4: The Experiences of Four Survivors with the Towards Healing Process (Report, January 2015); Report of Case Study No 8: Mr John Ellis's Experience of the Towards Healing Process and Civil Litigation (Report, January 2015); Report of Case Study No 16: The Melbourne Response (Report, July 2015); Redress and Civil Litigation Report (n 11).

223 Megan Neil, 'Redress Scheme Changes "Being Considered"', The West Australian (online, 28 June 2019) $<$ https://hewest.com.au/politics/law-and-order/redress-scheme-changes-being-considered-ng-s$1952506>$.

224 Intergovernmental Agreement (n 36) 19. 
'changes to the assessment framework' and 'changes to the [counselling and psychological component] model'. ${ }^{225}$ Other changes to the NRS Act and the NRS Rules require a complex two-stage voting process. ${ }^{226}$ Yes, change is possible. But it will require substantial renegotiation and a shift in position on increased costs. Despite the barriers, change is required to mend the frayed fabric of redress and ensure justice for survivors.

\section{APPENDIX: CHRONOLOGY OF EVENTS}

Note: A document with citations is available from the authors upon request.

\begin{tabular}{|c|c|}
\hline Date & Event \\
\hline \multicolumn{2}{|l|}{2012} \\
\hline $12 \mathrm{Nov}$ & $\begin{array}{l}\text { Royal Commission into Institutional Responses to Child Sexual Abuse ('Royal Commission') } \\
\text { is announced by Prime Minister Julia Gillard. }\end{array}$ \\
\hline \multicolumn{2}{|l|}{2013} \\
\hline 11 Jan & $\begin{array}{l}\text { Royal Commission's Terms of Reference are established and its six Commissioners are } \\
\text { appointed. }\end{array}$ \\
\hline \multicolumn{2}{|l|}{2015} \\
\hline 14 Sep & $\begin{array}{l}\text { Redress and Civil Litigation Report is released by the Royal Commission. This report makes } \\
75 \text { recommendations about redress, including the establishment of a national redress } \\
\text { scheme. }\end{array}$ \\
\hline \multicolumn{2}{|l|}{2016} \\
\hline 29 Jan & $\begin{array}{l}\text { Attorney-General George Brandis and Minister for Social Services Christian Porter announce } \\
\text { that the Commonwealth Government will 'lead the development of a national approach to } \\
\text { redress for survivors of institutional child sexual abuse'. }\end{array}$ \\
\hline May & $\begin{array}{l}\text { Taskforce on Redress for Survivors of Institutional Child Sexual Abuse ('Taskforce') is } \\
\text { established in the Department of Prime Minister and Cabinet. This Taskforce was tasked with } \\
\text { considering the Royal Commission's recommendations and implementing and administering } \\
\text { a redress scheme. }\end{array}$ \\
\hline $4 \mathrm{Nov}$ & $\begin{array}{l}\text { Attorney-General Brandis and Minister for Social Services Porter announce that the Federal } \\
\text { Government will establish a Commonwealth Redress Scheme. }\end{array}$ \\
\hline $16 \mathrm{Dec}$ & $\begin{array}{l}\text { The Independent Advisory Council on Redress ('Council') is established. The principal } \\
\text { purpose of the Council is to provide 'independent advice to the Minister on policies and } \\
\text { processes necessary to the design and implementation of the Commonwealth Redress } \\
\text { Scheme'. The Council is headed by Hon Cheryl Edwardes AM and includes representatives } \\
\text { from a number of survivor organisations and support groups, Indigenous and disability } \\
\text { organisations, experts in the fields of criminology and criminal justice and law, and former }\end{array}$ \\
\hline
\end{tabular}




\begin{tabular}{|c|c|}
\hline & $\begin{array}{l}\text { politicians. The Council met on seven occasions from February to November } 2017 \text { to discuss } \\
\text { the content of the proposed bill and provide recommendations to the Minister. }\end{array}$ \\
\hline \multicolumn{2}{|l|}{2017} \\
\hline 1 Feb & $\begin{array}{l}\text { Responsibility for the Taskforce moves from the Department of Prime Minister and Cabinet to } \\
\text { the Department of Social Services ('DSS'). Since then, DSS has been responsible for the } \\
\text { establishment of the scheme, including facilitating state, territory, and non-governmental } \\
\text { participation. }\end{array}$ \\
\hline 9 May & The Turnbull Government announces that the redress scheme will commence in July 2018. \\
\hline 19 Jun & $\begin{array}{l}\text { A resolution to establish the Joint Select Committee on oversight of the implementation of } \\
\text { redress related recommendations of the Royal Commission into Institutional Responses to } \\
\text { Child Sexual Abuse ('Joint Select Committee') is agreed to in the Senate. The House of } \\
\text { Representatives concurs with this resolution the following day. }\end{array}$ \\
\hline $19 \mathrm{Jul}$ & $\begin{array}{l}\text { State and territory governments are provided with copies of a draft National Redress bill that } \\
\text { envisions the participation of other jurisdictions. Other versions of the bill are provided on } 22 \\
\text { September } 2017 \text { and } 7 \text { February } 2018 \text {. }\end{array}$ \\
\hline 22 Sep & Key non-government organisations also receive copies of a draft National Redress bill. \\
\hline 26 Oct & $\begin{array}{l}\text { The Commonwealth Redress Scheme Bill ('CRS Bill') and the Commonwealth Redress } \\
\text { Scheme for Institutional Child Sexual Abuse (Consequential Amendments) Bill } 2017 \text { ('CRS } \\
\text { Bills') are introduced into Commonwealth Parliament. }\end{array}$ \\
\hline $6 \mathrm{Dec}$ & $\begin{array}{l}\text { CRS Bill is scrutinised in the Senate Standing Committee for the Scrutiny of Bills' Scrutiny } \\
\text { Digest } 15 \text { of } 2017 .\end{array}$ \\
\hline $15 \mathrm{Dec}$ & $\begin{array}{l}\text { Royal Commission's Final Report is presented to the Governor-General. The report is tabled } \\
\text { on } 5 \text { February } 2018 .\end{array}$ \\
\hline \multicolumn{2}{|l|}{2018} \\
\hline 13 Feb & Parliamentary Joint Committee on Human Rights report on the CRS Bill is published. \\
\hline $16 \mathrm{Feb}$ & $\begin{array}{l}\text { Senate Community Affairs Legislation Committee ('Senate Committee') holds its first hearing } \\
\text { on the CRS Bills in Canberra. It holds another hearing on } 6 \text { March } 2018 \text { in Melbourne. }\end{array}$ \\
\hline 9 Mar & $\begin{array}{l}\text { Prime Minister Turnbull announces that New South Wales and Victoria have agreed to join } \\
\text { the scheme. }\end{array}$ \\
\hline $28 \mathrm{Mar}$ & Senate Committee report on the CRS Bills is published. \\
\hline 1 May & $\begin{array}{l}\text { Premier of New South Wales ('NSW') and the Chief Minister of the Australian Capital Territory } \\
\text { ('ACT') sign the Intergovernmental Agreement on the National Redress Scheme for } \\
\text { Institutional Child Sexual Abuse. The Agreement set out how Commonwealth, state and } \\
\text { territory governments would work together to implement a national scheme. It has since been } \\
\text { signed by the Commonwealth and all state and territory governments. }\end{array}$ \\
\hline 1 May & $\begin{array}{l}\text { NSW becomes the first state to introduce legislation referring matters relating to the scheme } \\
\text { to the Commonwealth Parliament. }\end{array}$ \\
\hline 10 May & $\begin{array}{l}\text { The National Redress Scheme for Institutional Child Sexual Abuse Bill } 2018 \text { ('NRS Bill') and } \\
\text { the National Redress Scheme for Institutional Child Sexual Abuse (Consequential } \\
\text { Amendments) Bill } 2018 \text { ('NRS Bills') are introduced into Commonwealth Parliament. They are } \\
\text { referred to the Senate Committee. }\end{array}$ \\
\hline
\end{tabular}




\begin{tabular}{|c|c|}
\hline 23 May & $\begin{array}{l}\text { NSW referral legislation (National Redress Scheme for Institutional Child Sexual Abuse } \\
\text { (Commonwealth Powers) Bill 2018) receives royal assent and becomes law. }\end{array}$ \\
\hline 29 May & NRS Bills are passed by the House of Representatives without amendment. \\
\hline 31 May & $\begin{array}{l}\text { First major non-government institution (the Catholic Church) announces its intention to join } \\
\text { the scheme. }\end{array}$ \\
\hline 13 Jun & Victoria's referral legislation receives royal assent and becomes law. \\
\hline 15 Jun & Senate Committee report on the NRS Bills is published. It recommends the Bills' passage. \\
\hline 19 Jun & NRS Bills are passed by the Senate without amendment. \\
\hline 21 Jun & NRS Bills receive royal assent and become law. \\
\hline $1 \mathrm{Jul}$ & $\begin{array}{l}\text { National Redress Scheme for people who have experienced institutional child sexual abuse } \\
\text { commences. Institutions have until } 30 \text { June } 2020 \text { to opt in. }\end{array}$ \\
\hline 13 Aug & $\begin{array}{l}\text { National Redress Scheme for Institutional Child Sexual Abuse Assessment Framework } 2018 \\
\text { and National Redress Scheme for Institutional Child Sexual Abuse Direct Personal Response } \\
\text { Framework } 2018 \text { are tabled in the House of Representatives and the Senate. }\end{array}$ \\
\hline 20 Sep & Scheme commences in the ACT. \\
\hline 28 Sep & Queensland's adoption legislation commences. \\
\hline $80 \mathrm{Oct}$ & $\begin{array}{l}\text { First Joint Select Committee hearing is held in Melbourne. Other hearings are held in Sydney } \\
\text { on } 10 \text { October 2018, Brisbane on } 7 \text { November 2018, Newcastle on } 8 \text { November 2018, and } \\
\text { Canberra on } 28 \text { February } 2019 \text {. }\end{array}$ \\
\hline $1 \mathrm{Nov}$ & Tasmania's adoption legislation commences. \\
\hline $16 \mathrm{Nov}$ & Scheme commences in the Northern Territory. \\
\hline $22 \mathrm{Nov}$ & South Australia's adoption legislation commences. \\
\hline \multicolumn{2}{|l|}{2019} \\
\hline 1 Jan & Western Australia's adoption legislation commences. \\
\hline $2 \mathrm{Apr}$ & Joint Select Committee Final Report is tabled. \\
\hline
\end{tabular}

